Article

\title{
Suitability Zoning for Sustainable Drainage Systems (SuDSs): Application in a Basin in Southern Brazil
}

\author{
Moises Failache ${ }^{1, *(\mathbb{D})}$, Nívea Pons ${ }^{2}$, Osni Pejon ${ }^{1}$ and Lázaro Zuquette ${ }^{1, *(\mathbb{D})}$ \\ 1 Department of Geotechnics, São Carlos School of Engineering (USP-EESC), University of São Paulo, \\ São Carlos 13566-590, Brazil; pejon@sc.usp.br \\ 2 Natural Resources Institute, Federal University of Itajubá, Itajubá 37500-903, Brazil; npons@unifei.edu.br \\ * Correspondence: mffailache@usp.br (M.F.); lazarus1@sc.usp.br (L.Z.)
}

Citation: Failache, M.; Pons, N.; Pejon, O.; Zuquette, L. Suitability Zoning for Sustainable Drainage Systems (SuDSs): Application in a Basin in Southern Brazil.

Sustainability 2022, 14, 2577.

https://doi.org/10.3390/su14052577

Academic Editors: Stefano Morelli and Miklas Scholz

Received: 9 December 2021 Accepted: 10 February 2022 Published: 23 February 2022

Publisher's Note: MDPI stays neutral with regard to jurisdictional claims in published maps and institutional affiliations.

Copyright: (C) 2022 by the authors. Licensee MDPI, Basel, Switzerland. This article is an open access article distributed under the terms and conditions of the Creative Commons Attribution (CC BY) license (https:// creativecommons.org/licenses/by/ $4.0 /)$.

\begin{abstract}
The objective of this study was to propose a set of procedures to assess areas regarding the suitability of sustainable drainage systems (SuDSs) with application in a basin in the urban area of São Carlos (Brazil). The assessment was based on an analysis of 39 attributes reflecting the infiltration conditions that control the functional and constructive aspects of the systems, including subsurface drainability, stability, and groundwater contamination potential, which control the degree of suitability of each plot of land. The data obtained through engineering geological mapping procedures and physical principles were used to characterize the area, which resulted in the division of the basin into five SuDS suitability zones, ranging from favorable to restrictive. The proposed procedures proved to be efficient for analyzing the suitability of different SuDS types and the zoning of an area into terrain units. This approach can help planners identify the most appropriate SuDS types for a given unit, optimize the efficiency/cost relationship, and foresee potential environmental and construction-related challenges. In other words, this procedure enables the assessment of the suitability of SuDSs for different unit terrain types with inexpensive and environmentally efficient technological procedures and resources and can be applied at a fine geographic scale.
\end{abstract}

Keywords: SuDS; urban planning; engineering geological mapping; water infiltration; runoff; flood

\section{Introduction}

Urbanized areas have been increasing in developing countries, mainly due to population growth; population migration from smaller to larger urbanized areas; regional displacements due to social and economic conditions; and, within an urbanized area, displacement from more central to peripheral areas [1,2]. This increase in urbanized areas has led to the occupation of areas with very distinct environmental characteristics, from aquifer recharge areas to areas subject to hazardous events with different natural, quasi-natural, natural-technological, and anthropogenic sources [3-6].

The increase in urbanized areas generates a set of changes of different intensities in vegetation, relief, waters, geological materials, wetlands, etc. Such changes alter the dynamics of the environment, affecting, among other aspects, the distribution ratios of rainwater, i.e., the relationship between surface runoff and infiltration. The resulting changes to the processes involved may lead to increased overflow, flooding, and linear and marginal erosion. The runoff-infiltration relationship is influenced by changes in the conditions of the superficial layer of geological materials and by changes in micro- and mesorelief characteristics. The soil surface sealing effect (compaction, dispersivity, hardening) decreases the infiltration rate and, consequently, increases surface runoff, whereas the destruction of relief features decreases the surface storage capacity and rugosity [7]. These changes cause an increase in the volume and velocity of runoff water on hillsides, leading to an increase in the peak discharge into drainage channels and a decrease in the residence time of water on hillsides and, consequently, increasing flooding intensity in basins. 
Several procedures have been proposed to alter the partitioning between surface runoff and infiltration, with an emphasis on sustainable drainage systems (SuDSs) used in urban environments, roadworks, and special-use areas such as industrial parks. SuDSs have been developed since the 1990s, with a set of techniques and measures that can be adopted depending on the land use characteristics and, especially, on the environmental components, as shown by [1,2,8-19].

According to several studies, including [16,19-21], several techniques, structures, and/or systems for SuDSs based both on water collection and infiltration into geological materials were developed. The main strategies include filter strips, filter drains or perforated pipes, soakaways, swales, infiltration basins, extended detention basins, infiltration trenches, infiltration blankets, bioretention systems, constructed wetlands, ponds, pervious surfaces and pavement, sand filters, geocellular systems, and tree plantations, as well as strategies based on the collection, storage, and reuse or control of runoff, including rainwater harvesting systems, green roofs, proprietary treatment systems, and attenuation storage tanks.

When choosing and implementing a SuDS or combination of SuDSs, the following are the fundamental objectives: (1) decrease the surface runoff volume to minimize possible flooding, silting, and linear and marginal erosion, as well as overtopping of containment structures in drainage channels; (2) ensure that infiltrated waters do not trigger any events of a geological, geotechnical, or hydrological nature that may damage the elements that compose the anthropogenic environment and/or alter natural conditions, affecting biodiversity; and (3) ensure that infiltrated waters are not contaminated and, consequently, do not contaminate geological materials and subsurface waters.

Considering infiltration SuDSs, the aspects previously considered, and the studies by $[19,20]$, the technical and constructive feasibility for implementing these systems in an area should be assessed to obtain data that enable the following: an evaluation of the suitability of a large area for the minimum conditions necessary to install one or more systems; an evaluation and choice of a system or combination of systems that are appropriate for certain aspects of the environment; and the collection of data that allow the development and dimensioning of the system design and the use of appropriate materials and specific conditions for construction.

The adoption, design, and implementation of SuDSs depend on a set of characteristics of the environmental components that affect and may hinder their functionality. According to $[16,19,20,22]$, the following factors are considered essential in planning SuDS installation because they control the infiltration and subsurface drainage conditions and reflect possible problems arising from the infiltrated water volume: geological materials and infiltration capacity; depth of the saturated zone; subsurface flow conditions; water storage capacity in the geological environment; topography; occurrence of anthropogenic fills; the potential for subsidence or collapse; landslides, creeps, or other gravitational mass movements; piping; contamination due to the mobilization of existing chemical and/or biological components in the area; contamination due to infiltration of contaminated water; excess overland flow due to infiltration; and water from a contaminated saturated zone or infiltration water entering water, sewage, or wastewater systems.

The results of the use of SuDSs and their efficiency have been reported in different types of publications, which also describe the guidelines adopted in different regions and countries [23-36]. These publications are mainly associated with countries that have a temperate to cold climate and have applications at different levels and use types, including urban and rural areas and roadworks.

However, the environmental conditions are different in tropical climate regions, which are characterized by very deep regolith packages and very porous upper layers with high permeability, which allow considerable water storage in geological materials and the flow of liquids at high velocities. However, these areas have been undergoing anthropogenic urbanization activities that cover the geological materials with layers of concrete, asphalt, and other materials with low permeability, as well as compacting or excavation of the 
surface layers. All these conditions significantly decrease the infiltration rate, increasing runoff and, thereby, leading to more frequent flooding, including in areas where flooding did not previously occur, and this situation can be exacerbated by extreme rainfall events.

Floods stand out among the problems generated by the change in the relationship between infiltration and runoff caused by urbanization, and these events have affected urban centers at different magnitudes in virtually all Brazilian states. One of the urban centers that has been intensely affected in the last 20 years is the city of São Carlos (São Paulo state), especially along the Gregório Stream channel, affecting the central and more densely occupied region as well as roads that connect different portions of the urbanized area. Approximately $65 \%$ of the area of this basin is urbanized and has a very low infiltration rate (less than $0.05 \mathrm{~mm} /$ minute), which has generated very high volumes of runoff and frequent flooding in the last 20 years (more than 3/year) in the plain along the main drainage channel. Moreover, even the nonurbanized portion has been undergoing processes of compaction and excavation of geological materials, which have reduced the infiltration rate to values at which most rainfall events generate overland flow [37].

The adoption of SuDSs is a recommended sustainability option for urbanized areas with flood problems [36]. However, the evaluation of implementation of the different types of SuDSs depends on the data of the physical environment, which allow the determination of the suitability of the SuDS for each area of the city. Thus, the main objective of this study was to develop a group of basic procedures for assessing the conditions of an area regarding the suitability of installing SuDSs to increase infiltration and decrease flooding and other adverse events resulting from surface runoff, considering the environmental characteristics of tropical zones. To achieve this objective, an initial proposal was developed with the selection of attributes and parameter classes that positively or negatively affect the behavior of the SuDS. The group of procedures was applied to the Gregório Stream Basin to estimate the feasibility and to guide the adoption and implementation of SuDSs at the 1:10,000 scale in accordance with the basic environmental characteristics of a tropical region.

\section{Materials and Methods}

\subsection{Materials and Data Sources}

The following materials were used to conduct the study:

1. topographic map from the Geographical and Cartographic Institute of São Paulo at a 1:10,000 scale;

2. aerial photographs at the $1: 8000,1: 25,000$, and 1:60,000 scales;

3. IKONOS satellite images;

4. mechanical-manual augers;

5. double-ring infiltrometers;

6. PVC samplers; and

7. laboratory equipment for the geological and geotechnical characterization of geological materials.

The relief, geological and geotechnical, land use, infiltration conditions, and other necessary data to apply the proposed procedure were obtained from previous data developed by several authors and at different scales [37-42] associated with specific laboratory and field work. These data were used for the suitability assessment of SuDS types.

\subsection{Development of the Procedure}

The main purpose of implementing SuDSs is to contain runoff and the resulting environmental problems, such as flooding. To understand the relationship between SuDSs and flooding and erosion, which is the focus of the present study, Figure 1 shows a bowtie diagram with the steps and barriers, including the SuDS, to increasing the infiltration rate. 
Rainfall

Intense rainfal
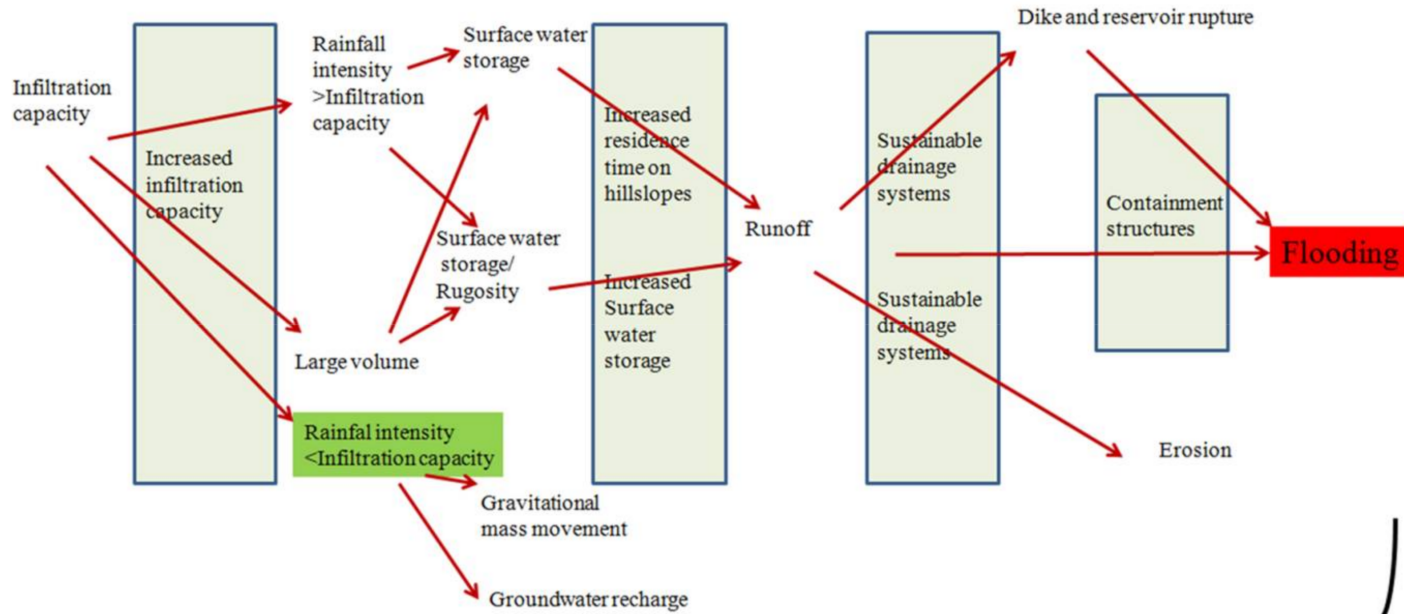

Long duration rainfall capacity
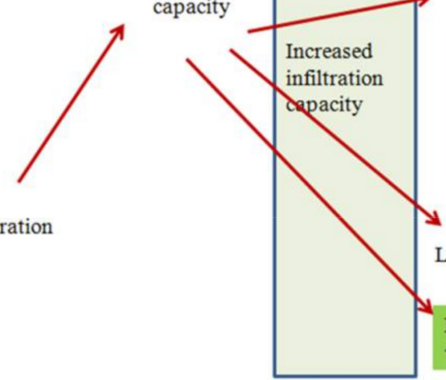

Groundwater recharge

Fault tree

(a)

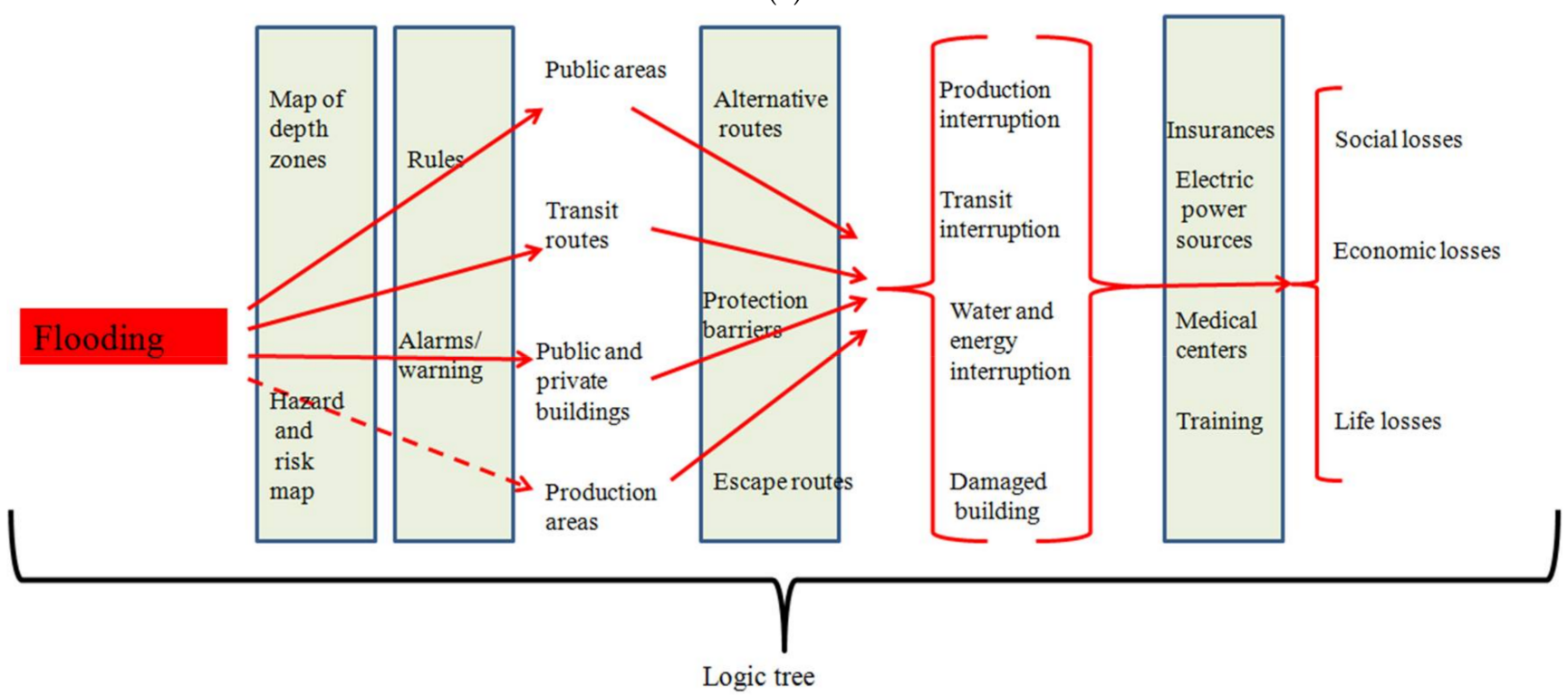

(b)

Figure 1. Bowtie diagram applied to flooding and the barrier position of the SuDS: (a) fault tree; (b) logic tree.

The bowtie diagram was developed with the fault tree (Figure 1a) representing the natural aspects that control flood occurrence (rain events, characteristics of geological materials, and relief); in other words, the causal aspects are related to the attributes that control infiltration conditions and the different aspects related to the flood event. In addition, structures and technological systems that can increase the runoff volume were considered, as were control and prevention measures and systems that minimize and/or avoid flood events. Figure $1 \mathrm{~b}$ presents the logic tree, which shows the potential consequences of flood events, mainly affecting infrastructure, buildings, and public services, as well as the measures that can be adopted to minimize the consequences, whether human or economic. 
The adoption and use of SuDSs is always related to the division of the terrain into hillsides, which provide a natural division with well-established boundaries that control the runoff flow to the drainage channels and are delineated based on topographic maps, aerial photographs, and satellite images. The conceptual model presented in Figure 2 shows the relationships and processes involved (infiltration, storage, redistribution, recharge of the saturated zone, and discharge) in the water flow path from the systems.

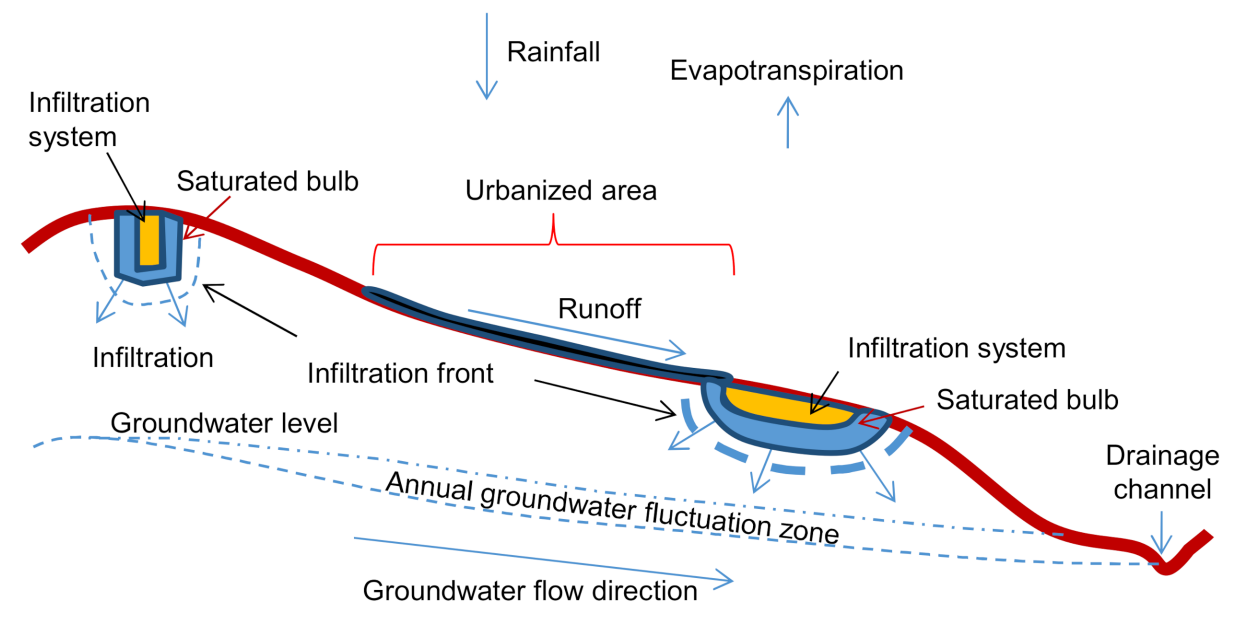

(a)

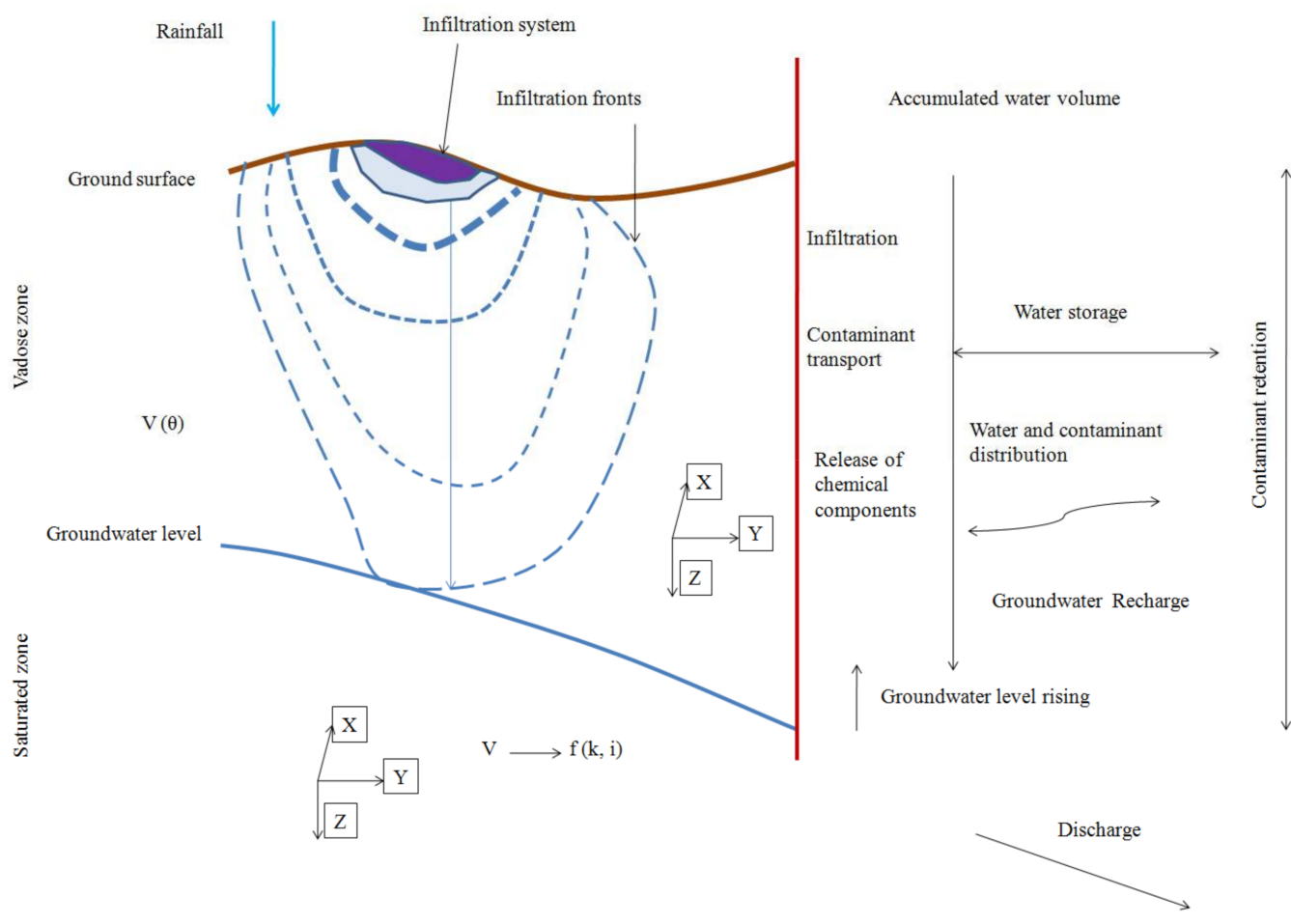

(b)

Figure 2. Hillside conceptual model used for the selection of attributes (a) and relations between drainage systems and water infiltration processes $(\mathbf{b})$.

On each hillside, there is the possibility of installing one or more infiltration-based drainage systems that can facilitate the infiltration and storage of a substantial water volume, thus affecting the environmental dynamics and potentially leading to the onset of environmental problems of different natures, such as the swelling of geological materials and contamination of groundwater. 
The suitability of SuDSs is supported by five aspects that should be jointly considered: the infiltration conditions that control the systems in terms of functionality and construction, the subsurface drainage conditions, the stability conditions, and the potential groundwater contamination conditions. Figure 3 shows the relationships between these five aspects and the environmental attributes of each plot of land, which affect the adoption and implementation of SuDSs. The considered attributes control the water flow in the unsaturated and saturated zone (velocity), the storage capacity (volume that can be stored in the pores), the retardation factor that reflects the capacity of geological materials to retain pollutants before they reach the saturated zone, possible construction problems, and the potential for dangerous events arising from the stability conditions.

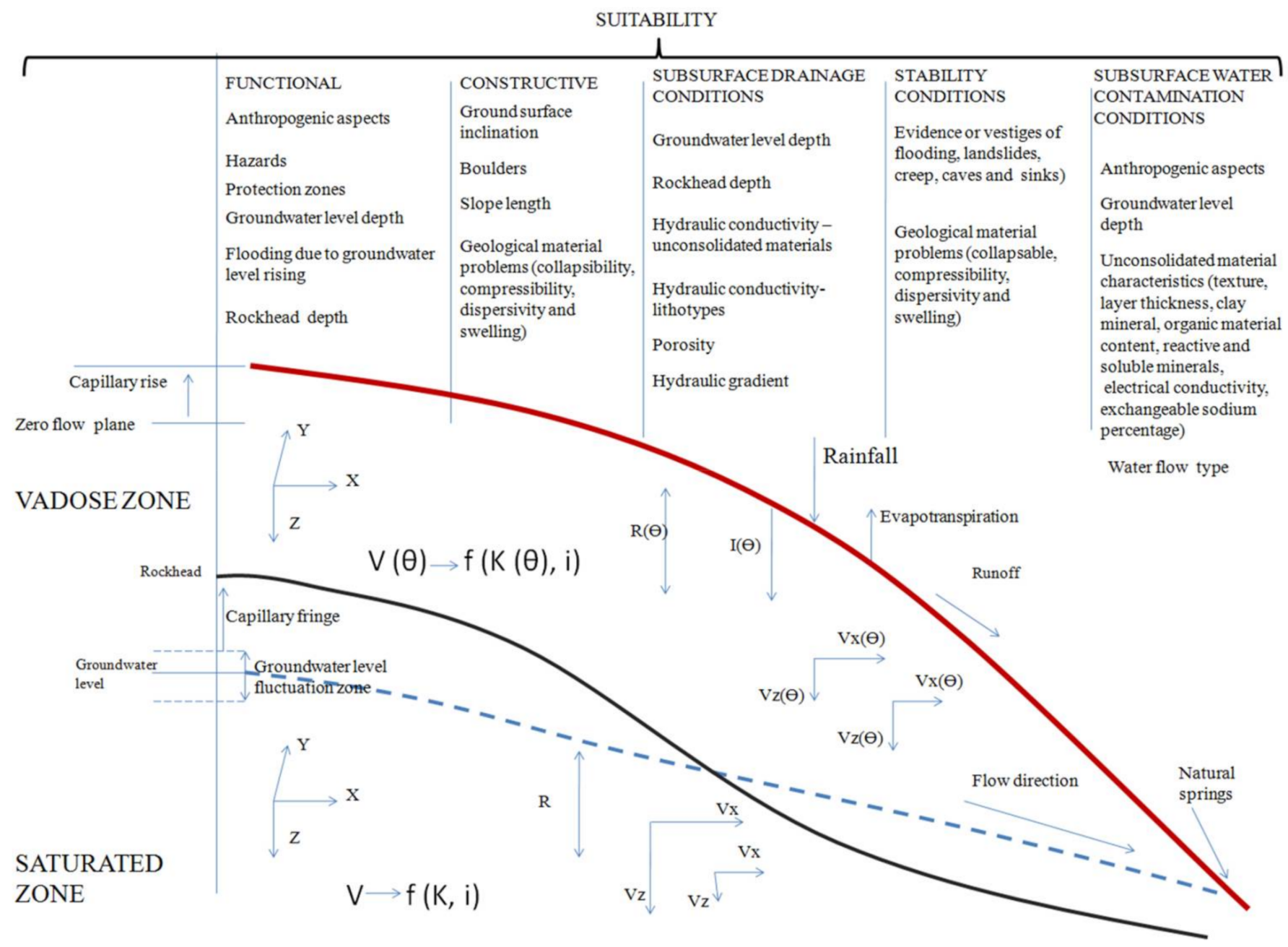

Figure 3. Relationship between the aspects that affect the suitability of sustainable drainage systems. Legend: V—flow velocity, $\mathrm{R}$-retardation factor, I-infiltration rate, $\theta$-volumetric moisture content.

Combining the conceptual model, the processes involved, the objectives of the systems, the land use relationships, and the attributes proposed by [43,44], a group of attributes was selected that affects the different aspects of the SuDS suitability analysis, as shown in Table 1 . The attributes were selected by analyzing the mechanisms and principles involved, through logic and fault trees, considering the set of attributes for each of the five aspects as well as the classes of each attribute that affect the viability of an area for the installation of one or more types of SuDS. 
Table 1. Attributes of suitability zoning for sustainable drainage systems; adapted from [43,44] with permission of University of São Paulo (1987, 1993).

\begin{tabular}{|c|c|c|c|c|c|c|c|}
\hline \multirow{2}{*}{ Component } & \multirow{2}{*}{ Attributes } & \multirow{2}{*}{ Parameters } & \multirow{2}{*}{ Dimension } & \multicolumn{4}{|c|}{ Categories } \\
\hline & & & & Favorable & Moderate & Severe & Restrictive \\
\hline \multirow[b]{3}{*}{ Relief } & Slope inclination & \multirow{2}{*}{ Classes/Categories } & $\%$ & $1-10$ & $10-20$ & $20-30$ & $>30$ \\
\hline & Channel frequency & & Channel $/ \mathrm{km}^{2}$ & $<1$ & $1-3$ & $3-5$ & $>5$ \\
\hline & Slope length & $\begin{array}{l}\text { Measured between } \\
\text { the watershed limit } \\
\text { and the thalweg }\end{array}$ & $\mathrm{m}$ & $>500$ & $300-500$ & $200-300$ & $<200$ \\
\hline \multirow{13}{*}{$\begin{array}{l}\text { Unconsolidated } \\
\text { materials }\end{array}$} & Regolith profile & $\begin{array}{l}\text { Description based on } \\
\text { variability }\end{array}$ & & $\begin{array}{l}\text { Homogenous and } \\
\text { continuous }\end{array}$ & - & - & $\begin{array}{l}\text { Heterogeneous and } \\
\text { discontinuous }\end{array}$ \\
\hline & Layer thickness & Surface layer & $\mathrm{m}$ & $>5$ & $3-5$ & $2-3$ & $<2$ \\
\hline & Texture & $\begin{array}{l}\text { Grain size } \\
\text { distribution }\end{array}$ & $\%$ & $\begin{array}{c}\text { Sandy with less than } \\
30 \% \text { of fines }\end{array}$ & $\begin{array}{c}\text { Sandy with } 30 \text { and } \\
50 \% \text { of fines }\end{array}$ & $\begin{array}{c}\text { Silt plus clay } \\
\text { between } 50 \text { and } 70 \%\end{array}$ & Silt plus clay $>70 \%$ \\
\hline & Permeability & $\begin{array}{l}\text { Hydraulic } \\
\text { conductivity }\end{array}$ & $\mathrm{cm} / \mathrm{s}$ & $>10^{-3}$ & $10^{-3}-10^{-4}$ & $10^{-4}-10^{-5}$ & $<10^{-5}$ \\
\hline & Porosity & - & $\%$ & $>50$ & $45-50$ & $40-45$ & $<40$ \\
\hline & \multirow[t]{3}{*}{ Mineralogy } & $\begin{array}{l}\text { Clay minerals } \\
\text { (categories to } \\
\text { estimate the potential } \\
\text { for swelling) }\end{array}$ & Mineral & No & $\begin{array}{l}\text { Kaolinite, gibbsite, } \\
\text { illites }\end{array}$ & $\begin{array}{c}\text { Smectites, } \\
\text { interstratified } \\
\text { minerals }<3 \%\end{array}$ & $\begin{array}{c}\text { Smectites, } \\
\text { vermiculites, } \\
\text { interstratified } \\
\text { minerals }\end{array}$ \\
\hline & & $\begin{array}{l}\text { Clay minerals } \\
\text { (categories for } \\
\text { estimating the } \\
\text { magnitude of the } \\
\text { retardation factor) }\end{array}$ & Mineral & $\begin{array}{c}\text { Smectites, } \\
\text { vermiculites, } \\
\text { interstratified } \\
\text { minerals }\end{array}$ & $\begin{array}{c}\text { Smectites, } \\
\text { interstratified } \\
\text { minerals }<3 \%\end{array}$ & $\begin{array}{l}\text { Kaolinite, gibbsite, } \\
\text { illites }\end{array}$ & No \\
\hline & & $\begin{array}{l}\text { Reactive and soluble } \\
\text { minerals }\end{array}$ & Mineral & No & No & $\begin{array}{c}\text { Sulfides, } \\
\text { carbonates }<0.5 \%\end{array}$ & $\begin{array}{c}\text { Sulfides, } \\
\text { carbonates }\end{array}$ \\
\hline & Boulders & $\begin{array}{c}\text { - Size } \\
\text { - Frequency } \\
\text { - Depth }\end{array}$ & & No & $\begin{array}{l}\text { Small, few, shallow } \\
\text { or on the ground } \\
\text { surface }\end{array}$ & $\begin{array}{l}\text { Large, few, shallow } \\
\text { or on the ground } \\
\text { surface }\end{array}$ & $\begin{array}{l}\text { Many boulders with } \\
\text { varying sizes and at } \\
\text { varying depths }\end{array}$ \\
\hline & $\mathrm{pH}$ & - & & $5-7.5$ & $7.5-8.5$ & & $>8.5$ \\
\hline & $\begin{array}{c}\text { Electrical } \\
\text { conductivity }\end{array}$ & - & $\mathrm{dS} / \mathrm{m}$ & $<1$ & $1-4$ & $4-6$ & $>6$ \\
\hline & $\begin{array}{c}\text { Exchangeable } \\
\text { sodium percentage }\end{array}$ & - & $\%$ & $<5$ & $5-10$ & $10-15$ & $>15$ \\
\hline & Organic material & - & $\%$ & $>3$ & $2-3$ & $1-2$ & $<1$ \\
\hline
\end{tabular}


Table 1. Cont.

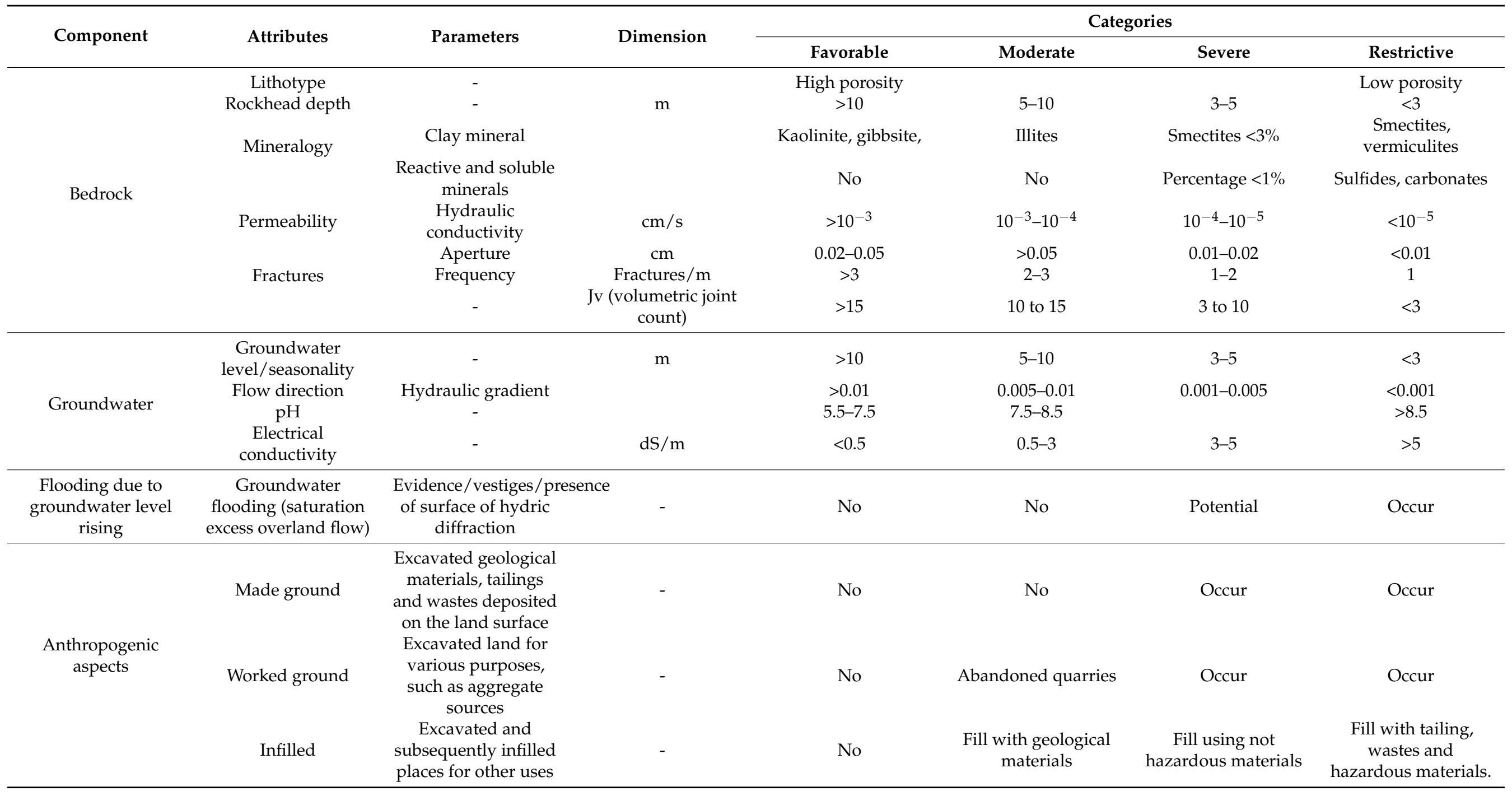


Table 1. Cont.

\begin{tabular}{|c|c|c|c|c|c|c|c|}
\hline \multirow{2}{*}{ Component } & \multirow{2}{*}{ Attributes } & \multirow{2}{*}{ Parameters } & \multirow{2}{*}{ Dimension } & \multicolumn{4}{|c|}{ Categories } \\
\hline & & & & Favorable & Moderate & Severe & Restrictive \\
\hline & Disturbed & $\begin{array}{l}\text { Areas that, due to } \\
\text { excavations for } \\
\text { various purposes, in } \\
\text { the shallow portions, } \\
\text { suffered collapses }\end{array}$ & - & No & - & Occur & Occur \\
\hline & Landscaped & $\begin{array}{l}\text { Areas that have } \\
\text { undergone } \\
\text { modifications for } \\
\text { different uses and } \\
\text { that do not fit into the } \\
\text { previous categories }\end{array}$ & - & No & $\begin{array}{l}\text { Golf course, sportive } \\
\text { areas, airports }\end{array}$ & Occur & Occur \\
\hline \multirow{8}{*}{ Hazard sources } & Flooding & Evidence & - & $\mathrm{No}$ & No & Occur & Occur \\
\hline & Creep & Evidence & - & No & No & Occur & Occur \\
\hline & Landslides & Evidence & - & No & No & Occur & Occur \\
\hline & $\begin{array}{c}\text { Collapsible } \\
\text { geological materials }\end{array}$ & $\begin{array}{c}\text { Porosity, } \\
\text { texture, } \\
\text { dry unit weight }\end{array}$ & - & No & Occur $<2$ m deep & $\begin{array}{l}\text { Occur with depth up } \\
\text { to } 5 \mathrm{~m}\end{array}$ & $\begin{array}{l}\text { Occur with depth up } \\
\text { to } 10 \mathrm{~m}\end{array}$ \\
\hline & Swelling & $\begin{array}{l}\text { Clay minerals, } \\
\text { smectite percentage }\end{array}$ & - & No & Occur $<2 \mathrm{~m}$ & $\begin{array}{l}\text { Occur in depth up to } \\
5 \mathrm{~m}\end{array}$ & $\begin{array}{l}\text { Occur in depth up to } \\
10 \mathrm{~m}\end{array}$ \\
\hline & Dispersivity & $\begin{array}{c}\text { Exchangeable } \\
\text { sodium percentage, } \\
\text { electrical } \\
\text { conductivity, } \\
\text { texture }\end{array}$ & - & No & Occur $<2 \mathrm{~m}$ & $\begin{array}{l}\text { Occur in depth up to } \\
5 \mathrm{~m}\end{array}$ & $\begin{array}{l}\text { Occur in depth up to } \\
10 \mathrm{~m}\end{array}$ \\
\hline & $\begin{array}{c}\text { Soluble geological } \\
\text { materials }\end{array}$ & $\begin{array}{l}\text { Soluble minerals, } \\
\text { carbonates }\end{array}$ & - & No & No & Occur $<1 \%$ & Occur \\
\hline & Caves/sinks & Evidence & - & No & No & Occur & Occur \\
\hline \multirow{3}{*}{ Special aspects } & \multirow{3}{*}{ Protection zones } & Groundwater well & - & No & No & Occur & Occur \\
\hline & & Natural springs & - & No & No & Occur & Occur \\
\hline & & Lakes, reservoirs & - & No & No & Occur & Occur \\
\hline
\end{tabular}


The attributes were selected considering the different aspects that affect the infiltration and storage capacity as well as the design, implementation, and efficiency of the SuDS. The functional suitability depends on water infiltration and ground storage, which are controlled by the rockhead depth, hazard, groundwater level depth, anthropogenic uses or changes, and protection zones of wells and springs. The construction suitability considers the potential problems with the excavation and system stability, such as shallow rockhead and groundwater level depth, boulders, slope characteristics, and geological material characteristics. The subsurface drainage and the potential groundwater contamination conditions are related because the contaminants are transported by water. Both aspects depend on the water velocity (permeability of the geological materials and hydraulic gradient), groundwater level depth, porosity and contaminant attenuation capacity by geological material (sorption, $\mathrm{pH}$, Eh, soluble minerals), and anthropogenic aspects. The stability conditions of the hillslopes or land portion are related to geological and geotechnical hazards as well as collapsible, swelling, compressible, and dispersive geological materials. The classes were defined considering the attributes and the limits that may interfere with SuDS' suitability of implementation.

Moreover, Table 1 was elaborated considering the different functions and characteristics of the SuDS (Figures 2 and 3) and spreadsheets elaborated by [43,44] for the development of engineering geological mapping, which is the general procedure to acquire environmental data for use in territorial and environmental planning $[45,46]$ at different scales and for different purposes. The attributes were grouped by the different environmental components (relief, unconsolidated materials, bedrock, groundwater, anthropogenic aspects, hazard sources, and protection zones), and the respective classes were defined in terms of the favorability and/or constraints to the aspects (functionality and construction, subsurface drainage conditions, stability conditions, and potential groundwater contamination conditions) that affect the feasibility of the SuDS. These classes can also be used to guide detailed site investigations for project development and implementation. Arranging the attributes in this way guides users in the obtainment of data from previous studies as well as in the design of specific studies for the purpose at hand. Moreover, this approach allows the data treatment to be developed by different computational resources (GIS and electronic spreadsheets) applying different methods (AHP, entropy, overlay, weight methods, rating methods, fuzzy theory, matrices, statistical methods, score counting, and methods that use a combination of these methods) and considering different terrain units such as hillsides, specific slopes, drainage basins, regular grids, and other natural terrain divisions. The range of values adopted for the classes allows them to be widely applied in regions located in tropical climate zones with the aforementioned intrinsic characteristics. The number of attributes in Table 1 can be reduced or increased according to the specific characteristics of the environmental components of a region. The application of the attributes should follow a previously chosen sequence, as presented in Figure 4, which will result in classes for each aspect of suitability.

Figure 4 shows the diagram and logic trees used to analyze the interaction of the attributes to define the suitability of an area for installing one more type of SuDS. In this figure, attributes are associated with functional and constructive constraints, and logic trees are associated with attribute classes that are favorable, moderate, severe, and restrictive (represented by the coloring sequences). These sequences are applied when analyzing an area to assess the degree of suitability for the analyzed aspect.

The paths indicated by line segments/arrows of different colors in Figure $4 b, d$ indicate associations that generate different categories (restrictive, severe, moderate, and favorable). These categories are used for the respective zoning regarding the suitability of the areas for the different types of SuDSs. The favorable class does not have constraints and does not affect any of the five aspects negatively. In the moderate class, constraints can be overcome with adaptations in the design and execution. In the severe and restrictive classes, the constraints impose great difficulty in implementing SuDSs. 


\begin{tabular}{llllll}
$\begin{array}{l}\text { HAZARD } \\
\text { PREDISPOSITION }\end{array}$ & $\begin{array}{l}\text { ANTHROPOGENIC } \\
\text { ASPECTS } \\
\text { (STORAGES } \\
\text { EXCAVATIONS, } \\
\text { FILLS) }\end{array}$ & $\begin{array}{l}\text { PROTECTION } \\
\text { ZONES }\end{array}$ & $\begin{array}{l}\text { GROUNDWATER } \\
\text { LEVELDEPTH }\end{array}$ & $\begin{array}{l}\text { FLOODING DUE } \\
\text { TOGROUNDWATER } \\
\text { LEVEL RISING }\end{array}$ & ROCKHEAD DEPTH \\
$\begin{array}{l}\text { Landslides } \\
\text { Creep }\end{array}$ & Presence & Presence & $<3 \mathrm{~m}$ & $\begin{array}{l}\text { Potential or/and } \\
\text { evidence }\end{array}$ & $<3 \mathrm{~m}$ \\
$\begin{array}{l}\text { Flooding } \\
\text { Caves/ } \\
\text { Sinks }\end{array}$ & & & & \\
\hline
\end{tabular}

Functional constraints

SUDS

Constructive constraints

\begin{tabular}{|c|c|c|c|}
\hline$>30 \%$ & $\begin{array}{l}\text { At surface } \\
\text { or/and shallow }\end{array}$ & $<200 \mathrm{~m}$ & $\begin{array}{l}\text { Dispersivity } \\
\text { Swelling } \\
\text { Compressibility } \\
\text { Collapsibility }\end{array}$ \\
\hline INCLINATION & BOULDERS & SLOPE LENGTH & $\begin{array}{l}\text { POTENTIAL PROBLEMS } \\
\text { ASSOCIATED TO } \\
\text { GEOLOGICAL MATERIAL } \\
\text { CHARACTERISTICS }\end{array}$ \\
\hline
\end{tabular}

(a)
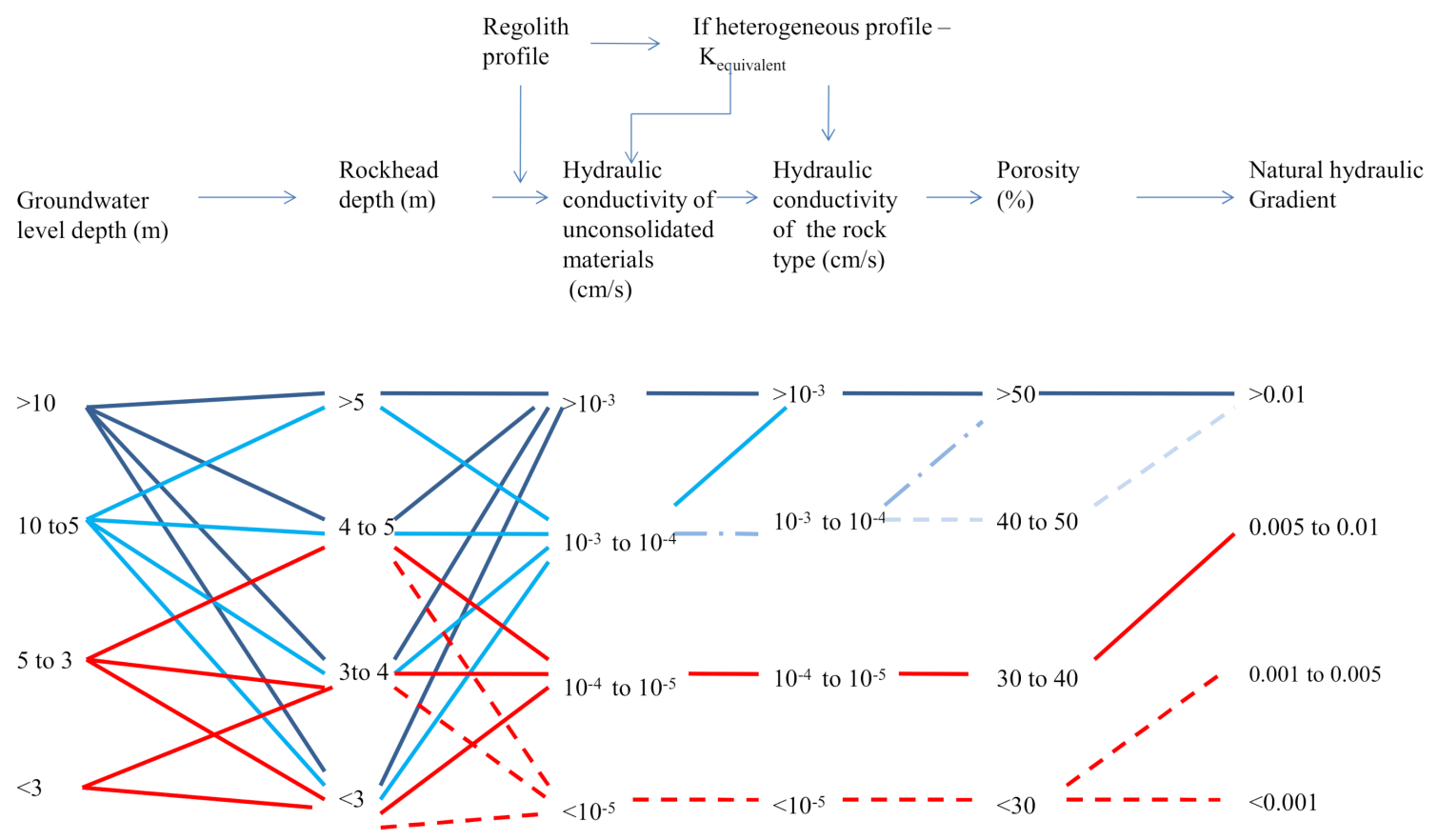

Red path - Restrictive condition

Light blue path - Moderate condition

Light blue and dashed line path - Moderate condition
Mixed color path - Severe condition

Dark blue path - Favorable condition

Light blue and dashed -dotted line path - Moderate condition

(b)

Figure 4. Cont. 


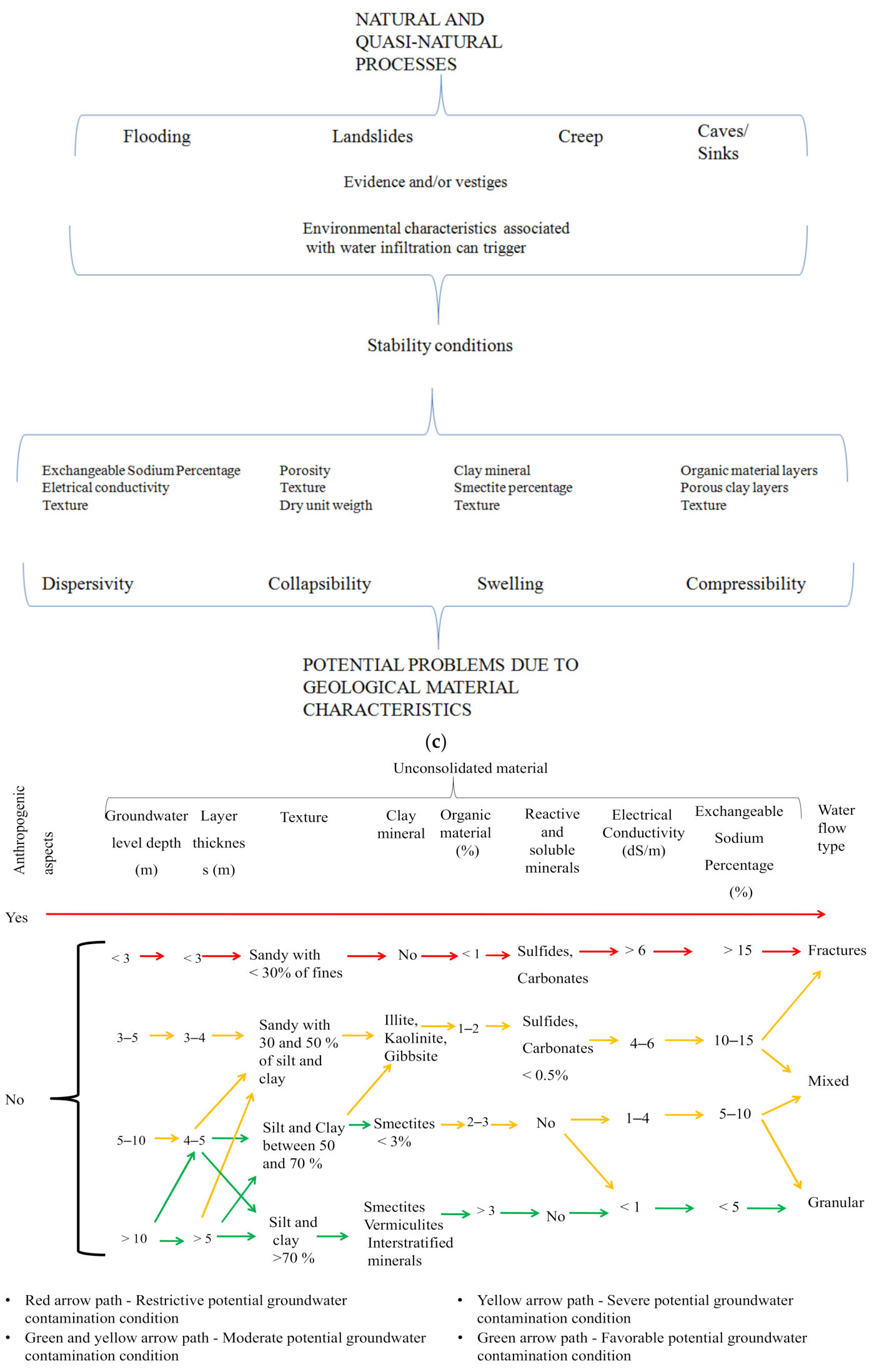

(d)

Figure 4. Diagrams and logic trees: (a) functional and constructive constraints, (b) subsurface drainage conditions, (c) stability conditions, and (d) potential groundwater contamination conditions. 


\subsection{Application of the Proposed Procedure}

Figure 5 shows a general flowchart with the main works conducted in this study presented sequentially and with the respective main objectives driving the application of the proposed procedure. The activities were grouped into four steps considering the collection, processing, and analysis of data relevant to the different environmental components. Figure 6 shows a detailed flowchart of the steps to determine the SuDS's suitability to the study area.

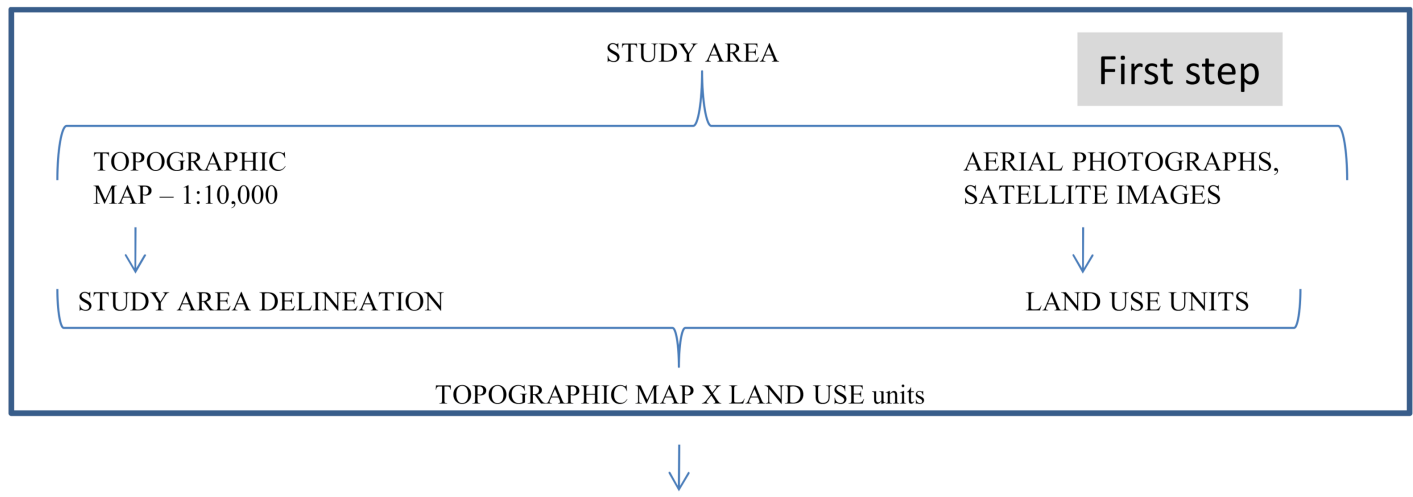

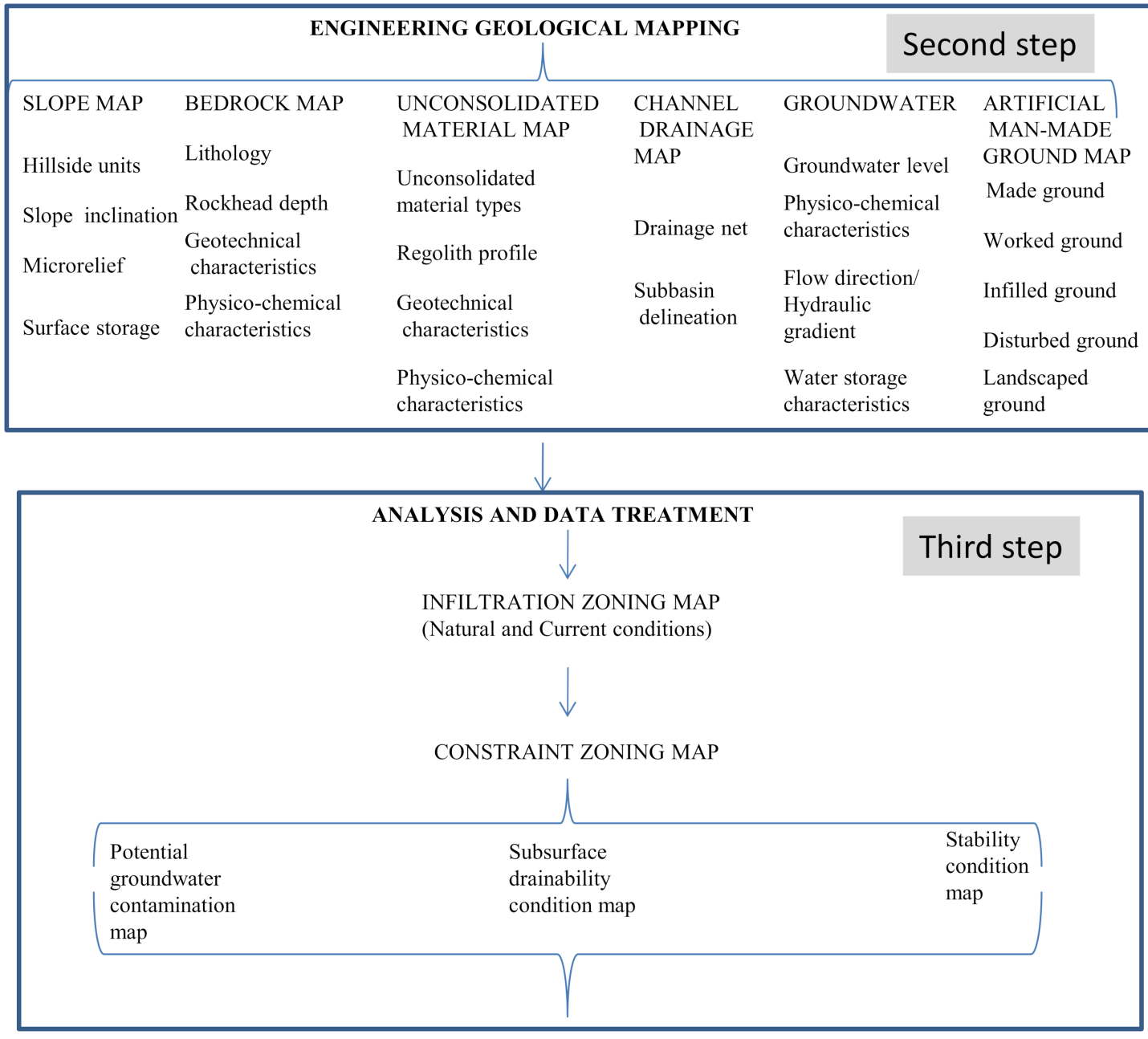

Figure 5. Flowchart of the study steps. 


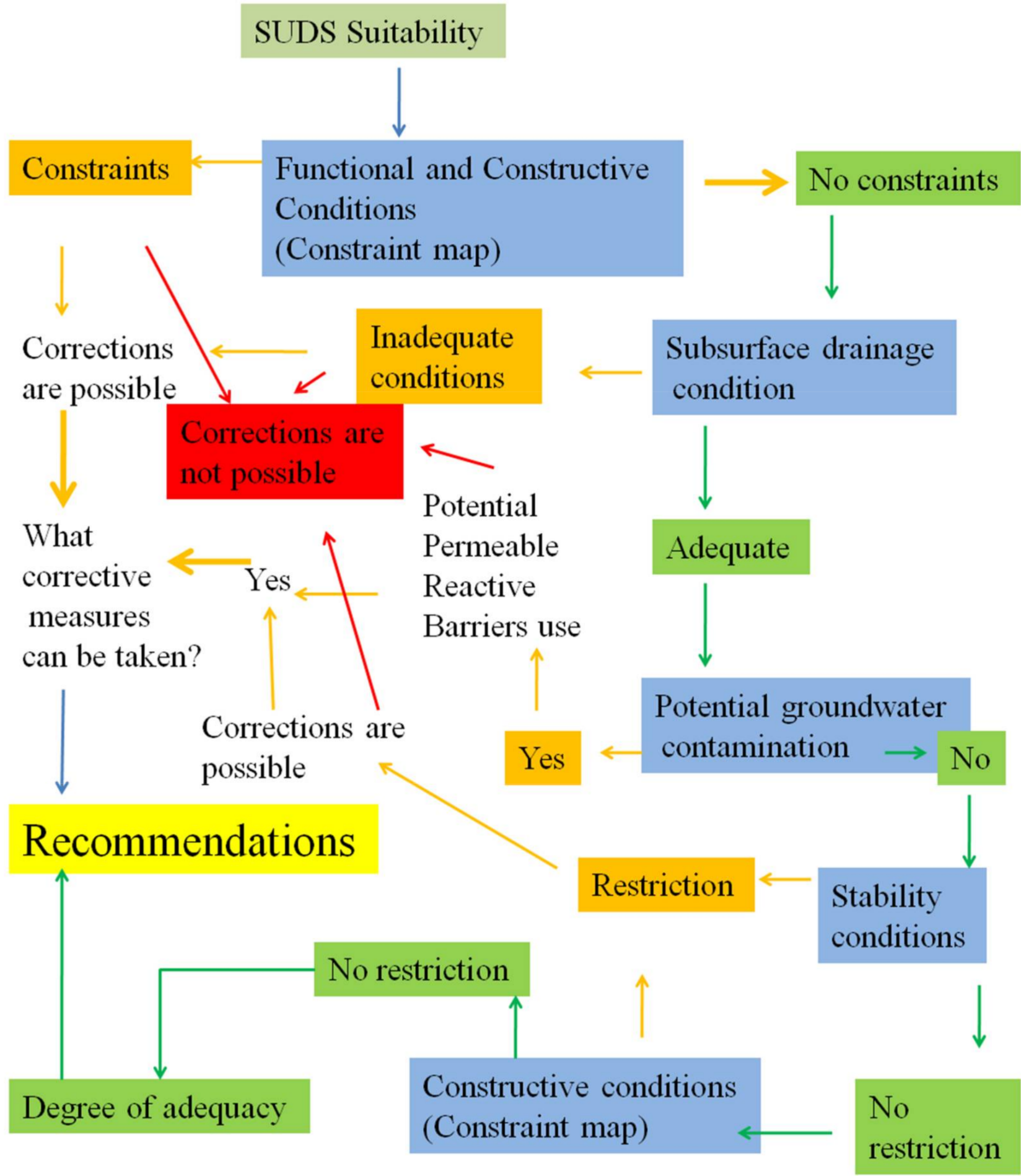

Figure 6. Flowchart for sustainable drainage system (SuDS) suitability zoning.

\section{Results}

\subsection{Characterization of the Area}

The Gregório Stream Basin, located in the urban area of the city of São Carlos, São Paulo state, Brazil (Figure 7), has been the subject of geological and geotechnical studies by different authors and at different scales. Previous data from these studies were selected, and other data were obtained from current surveys, which allowed the development of a set of cartographic products. 

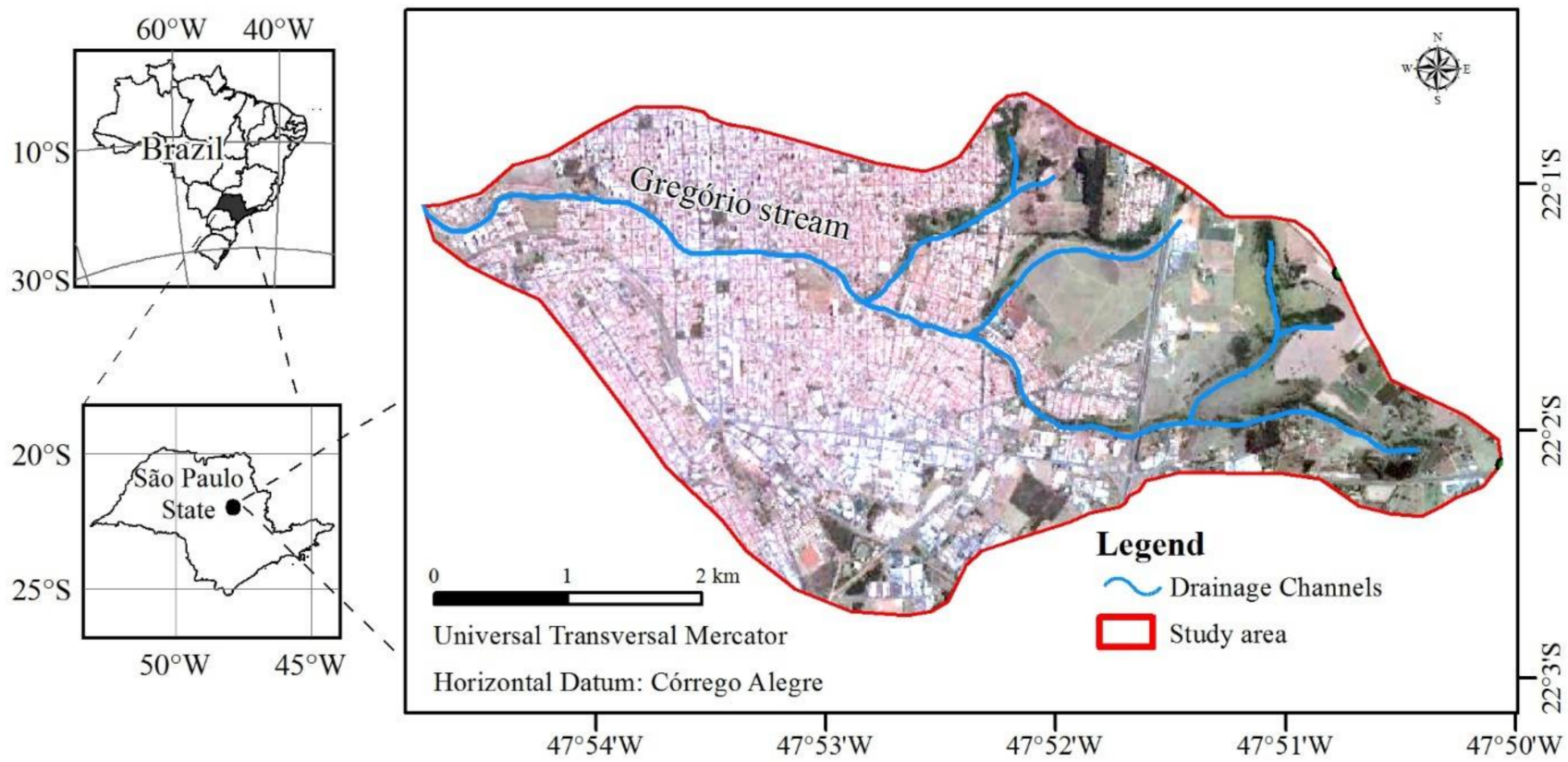

Figure 7. Location of the study basin (Gregório Stream Basin, São Carlos), São Paulo state, Brazil.

Figure 8a shows the topographic map, with the set of drainage channels prior to urbanization associated with the delimitation of the hillsides. In this map, the network of drainage channels, prior to urbanization, conditioned the distribution of water to several points, which generated a longer time of concentration than the current concentration time for the basin in question. Discharge into the main channel occurred through 15 channel outlets distributed in the basin; so, the flow of water into the main channel exhibited a staggered behavior in time and positioning along the main channel and, therefore, did not create high flow rates and short peak times. In the basin, there are three groups of hillsides that condition different surface runoff behaviors (Figure 8a): group A, in which the water flows directly into the Gregório Stream channel; group B, which conditions the flow to the tributaries; and group $\mathrm{C}$, which concentrates the water in the more upstream portions of the channels.

Table 2 shows the geological formations with the main lithotypes and basic characteristics. Figure $8 \mathrm{~b}$ shows the map of geological materials (unconsolidated and bedrock), and Table 3 shows the characteristics of the vertical profile of each unit. The map was produced by combining data from the cited studies and specific fieldwork and in situ characterization and sampling. In the basin under study, there are 11 units characterized by profiles consisting of different variations in regoliths and lithotypes. The unconsolidated materials that compose the different regoliths are alluvial, sandy-clayey, and sandy transported materials, residuals of the lithotypes of the Botucatu, Serra Geral, and Itaqueri formations (Supplementary Material, Table S1); the main geological-geotechnical characteristics are presented in Supplementary Material, Table S2. These materials are combined in different ways, generating regoliths with thicknesses ranging from $1 \mathrm{~m}$ to more than $15 \mathrm{~m}$, with a predominance of values lower than $10 \mathrm{~m}$. Notably, the surface layers condition the viability and efficiency as well as the choice of the type of SuDS.

Figure $8 \mathrm{c}$,d shows the maps of the groundwater level depth and rockhead depth, respectively, considering the classes shown in Table 1. Significant parts of the basin had estimated groundwater level depths and rockhead depths shallower than $5 \mathrm{~m}$. 


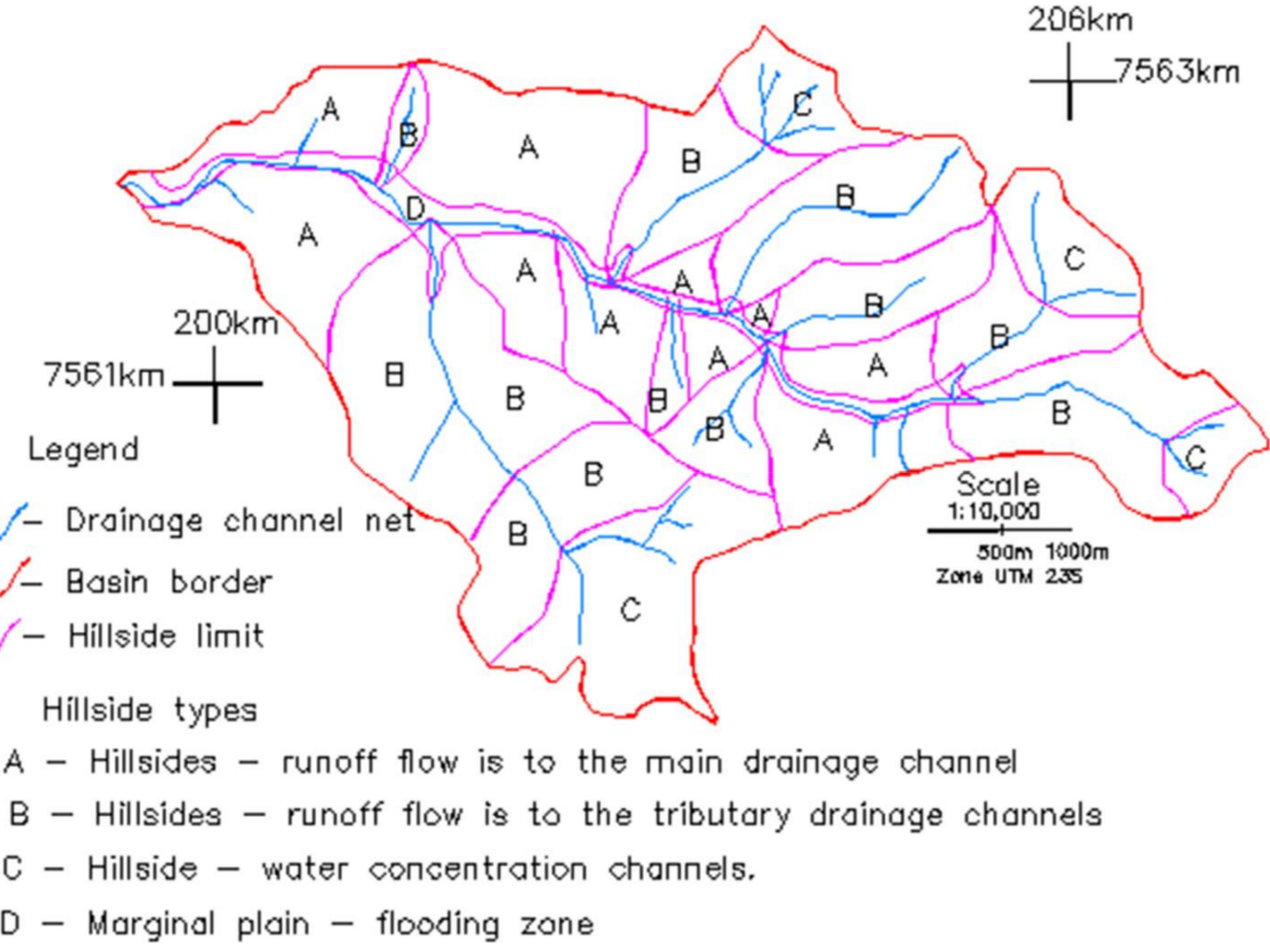

(a)

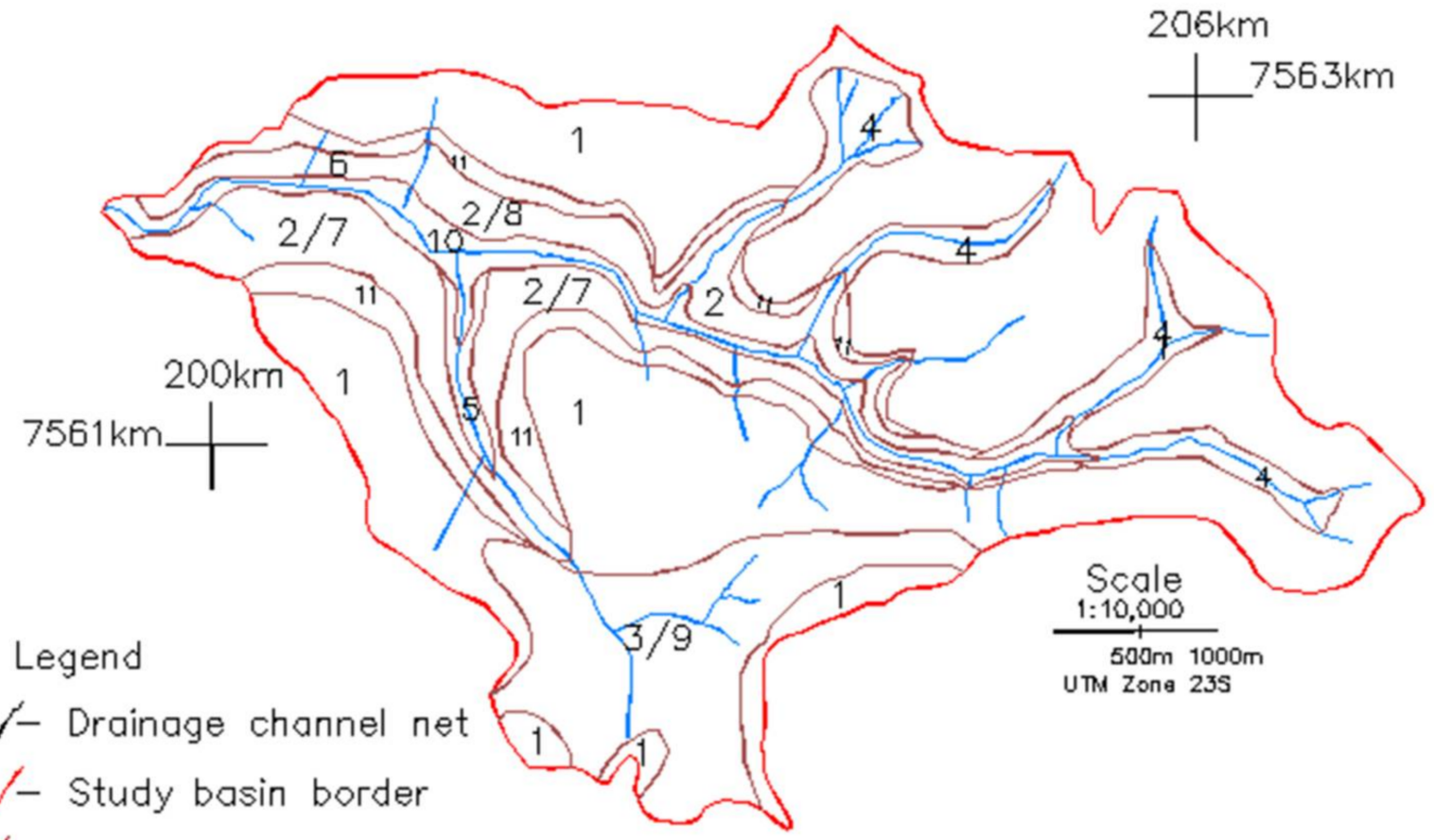

/ Limit between geological material units

1...2.. - Geological material units

(Unit explanation in the Table 3, 4 and 5)

(b)

Figure 8. Cont. 


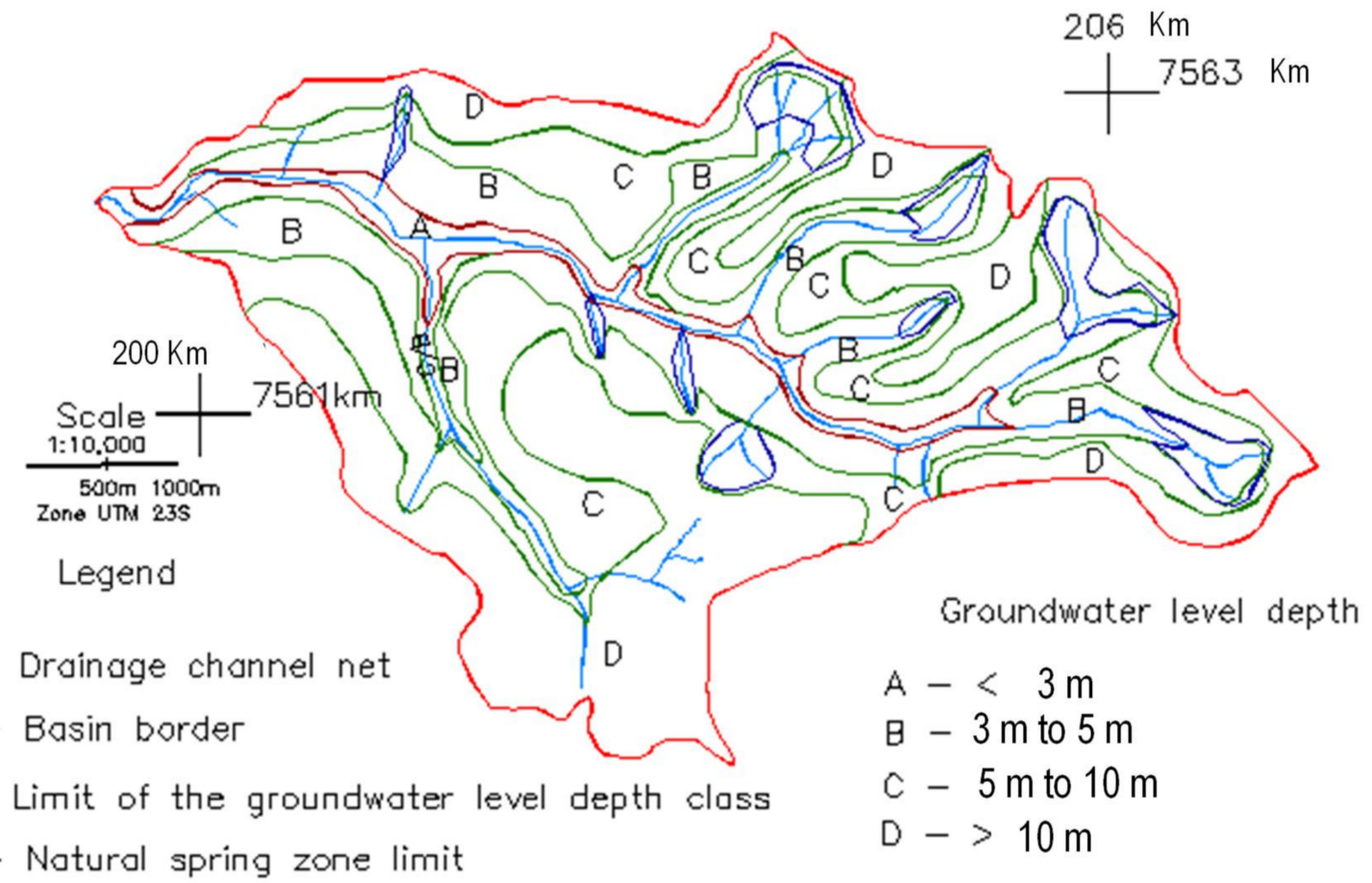

(c)

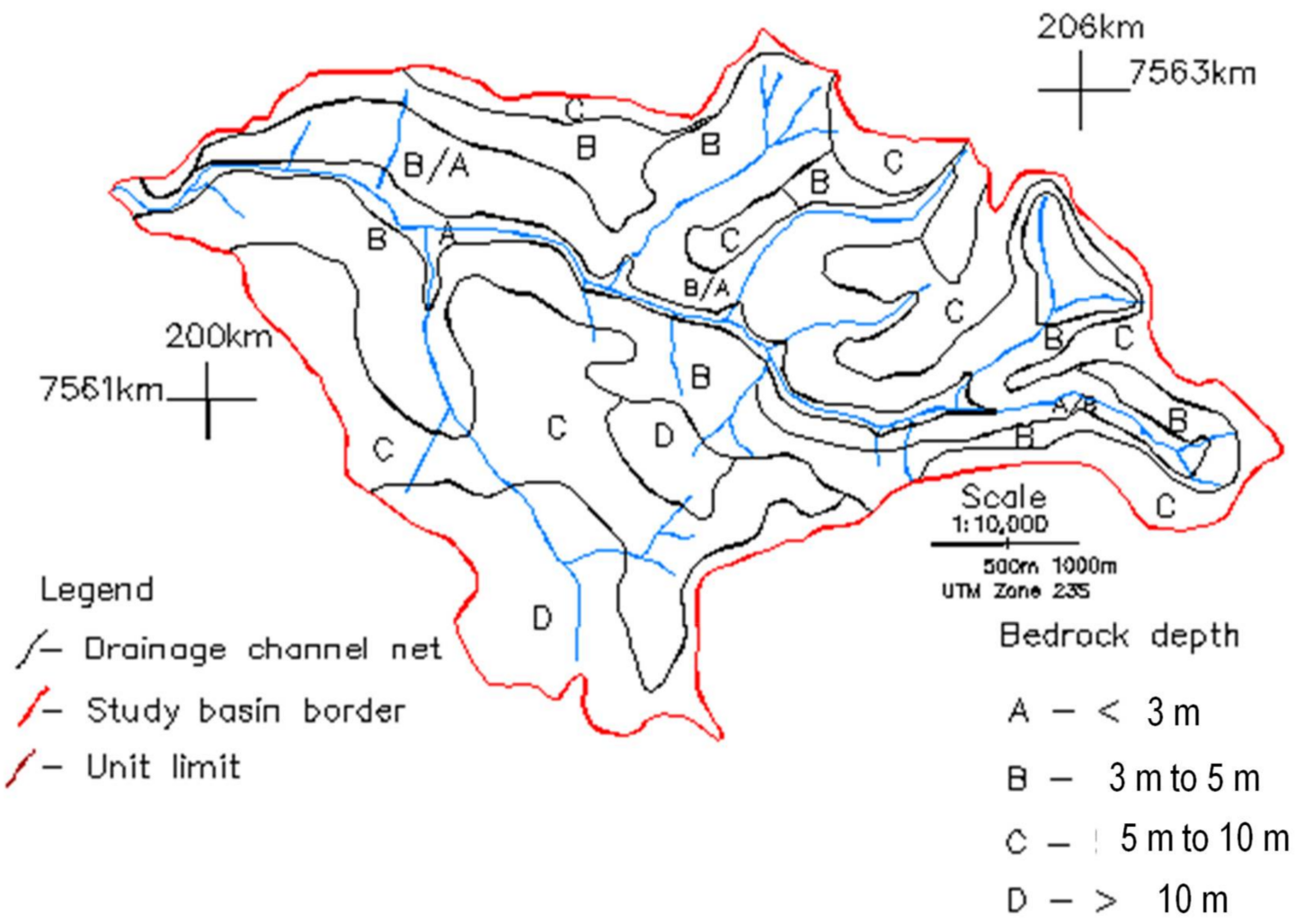

(d)

Figure 8. Basic maps of the study basin. Hillside and topographical conditions (a), geological materials (b), groundwater level depth (c), and rockhead depth (d). 
Table 2. Main geological formations and lithotypes in the study basin.

\begin{tabular}{|c|c|c|c|c|c|}
\hline Era & Period & Formation & Lithologies & Characteristics & Water Flow Type \\
\hline Cenozoic & Paleocene/Eocene & Itaqueri & $\begin{array}{l}\text { Moderate cemented } \\
\text { sandstones, } \\
\text { siltstones/claystones, } \\
\text { conglomerates }\end{array}$ & $\begin{array}{c}\text { These lithologies are in layers } \\
\text { intercalated with different } \\
\text { thicknesses. }\end{array}$ & $\begin{array}{l}\text { The sandstones have } \\
\text { good water storage } \\
\text { conditions, and the flow } \\
\text { is predominantly porous; } \\
\text { however, the small } \\
\text { thicknesses of the layers } \\
\text { do not support high } \\
\text { productivity of wells. }\end{array}$ \\
\hline \multirow[t]{2}{*}{ Mesozoic } & Cretaceous & Serra Geral & $\begin{array}{l}\text { Basalt intercalated with } \\
\text { very cemented sandstone } \\
\text { layers of the Botucatu } \\
\text { Formation }\end{array}$ & $\begin{array}{l}\text { Layers of fractured basalts } \\
\text { ranging from massive to those } \\
\text { containing } \\
\text { vesicular/amygdaloidal } \\
\text { structures (dense basalts, } \\
\text { vesicular-amygdaloidal basalts, } \\
\text { and basaltic breccias). } \\
\text { Layers of sandstones of small } \\
\text { thickness in the order of meters, } \\
\text { variable continuity, with } \\
\text { outcrops of sandstones and } \\
\text { basalt in different sites in the } \\
\text { main valley. }\end{array}$ & $\begin{array}{l}\text { Lithologies with fracture } \\
\text { flow and predominance } \\
\text { of horizontal flow due to } \\
\text { lava interflow } \\
\text { discontinuities. }\end{array}$ \\
\hline & Cretaceous/Jurassic & Botucatu & $\begin{array}{l}\text { Very well-cemented } \\
\text { sandstones } \\
\text { Very low to low cemented } \\
\text { sandstones (friables) }\end{array}$ & $\begin{array}{l}\text { The sandstone package is } \\
\text { usually associated with steep } \\
\text { scarps, very fractured and with } \\
\text { thicknesses less than } 100 \mathrm{~m} \text {. } \\
\text { The layer thicknesses can reach } \\
\text { values higher than } 150 \mathrm{~m} \text {. }\end{array}$ & $\begin{array}{l}\text { The water flow is } \\
\text { predominantly by } \\
\text { vertical fractures. } \\
\text { Porous water flow with } \\
\text { high transmissivity. }\end{array}$ \\
\hline
\end{tabular}

Table 3. Characteristics of the units in terms of the layers that constitute the profile.

\begin{tabular}{|c|c|c|c|c|c|}
\hline $\begin{array}{c}\text { Unit } 1 \text { (Layer } \\
\text { Type/Limit Type } \\
\text { between Layers) }\end{array}$ & Unit 2 & Unit 3 & Unit 4 & Unit 5 & Unit 6 \\
\hline $\begin{array}{l}\text { Sandy transported } \\
\text { Distinct/wavy }\end{array}$ & $\begin{array}{l}\text { Sandy transported } \\
\text { Distinct/wavy }\end{array}$ & $\begin{array}{l}\text { Sandy transported } \\
\text { Distinct/wavy }\end{array}$ & $\begin{array}{c}\text { Residual from } \\
\text { Itaqueri Formation } \\
\text { Diffuse/irregular }\end{array}$ & $\begin{array}{c}\text { Clayey sand } \\
\text { transported } \\
\text { Distinct/wavy }\end{array}$ & $\begin{array}{c}\text { Clay transported } \\
\text { with boulders and } \\
\text { rock blocks } \\
\text { Diffuse/irregular or } \\
\text { occluded }\end{array}$ \\
\hline Residual from & Residual from Serra & Residual from & Saprolite & Residual from Serra & Saprolite \\
\hline Itaqueri Formation & Geral Formation & Botucatu Formation & Diffuse/irregular & Geral Formation & Diffuse/irregular or \\
\hline $\begin{array}{c}\text { Diffuse/irregular } \\
\text { Saprolite }\end{array}$ & $\begin{array}{c}\text { Diffuse/irregular } \\
\text { Saprolite }\end{array}$ & Distinct/wavy & or occluded & $\begin{array}{c}\text { Diffuse/irregular } \\
\text { Saprolite }\end{array}$ & occluded \\
\hline $\begin{array}{l}\text { Saprolite } \\
\text { Diffuse/irregular or } \\
\text { occluded }\end{array}$ & $\begin{array}{l}\text { Daprolite } \\
\text { Diffuse/irregular or } \\
\text { occluded }\end{array}$ & $\begin{array}{c}\text { Saprolite } \\
\text { Indistinct/irregular }\end{array}$ & Weathered rock & $\begin{array}{l}\text { Daprolite } \\
\text { occluded }\end{array}$ & Weathered rock \\
\hline $\begin{array}{c}\text { Weathered rock } \\
\text { Rock }\end{array}$ & $\begin{array}{c}\text { Weathered rock } \\
\text { Rock }\end{array}$ & $\begin{array}{c}\text { Weathered rock } \\
\text { Rock }\end{array}$ & Rock & $\begin{array}{c}\text { Weathered rock } \\
\text { Rock }\end{array}$ & Rock \\
\hline Unit 7 & Unit 8 & Unit 9 & Unit 10 & Unit 11 & \\
\hline $\begin{array}{c}\text { Residual from Serra } \\
\text { Geral Formation } \\
\text { Diffuse/irregular }\end{array}$ & $\begin{array}{c}\text { Saprolite } \\
\text { Diffuse/irregular or } \\
\text { occluded }\end{array}$ & $\begin{array}{c}\text { Residual from } \\
\text { Botucatu Formation } \\
\text { Distinct/wavy }\end{array}$ & $\begin{array}{l}\text { Alluvial transported } \\
\text { Indistinct/irregular }\end{array}$ & $\begin{array}{c}\text { Sandy transported } \\
\text { Distinct/wavy }\end{array}$ & \\
\hline $\begin{array}{c}\text { Saprolite } \\
\text { Diffuse/irregular or } \\
\text { occluded }\end{array}$ & Weathered rock & $\begin{array}{c}\text { Saprolite } \\
\text { Indistinct/irregular }\end{array}$ & $\begin{array}{c}\text { Residual from Serra } \\
\text { Geral Formation } \\
\text { Diffuse/irregular } \\
\text { Saprolite }\end{array}$ & $\begin{array}{c}\text { Residual from } \\
\text { Itaqueri Formation } \\
\text { Diffuse/irregular } \\
\text { Saprolite }\end{array}$ & \\
\hline Weathered rock & Rock & Weathered rock & $\begin{array}{c}\text { Diffuse/irregular or } \\
\text { occluded }\end{array}$ & $\begin{array}{c}\text { Diffuse/irregular or } \\
\text { occluded }\end{array}$ & \\
\hline Rock & & Rock & $\begin{array}{c}\text { Weathered rock } \\
\text { Rock }\end{array}$ & $\begin{array}{c}\text { Weathered rock } \\
\text { Rock }\end{array}$ & \\
\hline
\end{tabular}




\subsection{Analyses}

According to the data contained in the maps in Figure 9 and Table 2 and Supplementary Material Table S1 and Table S2, analyses were performed based on the set of attributes and relationships shown in the diagrams of Figures 3 and 4 . The main constraints considered for the installation of a SuDS are the areas with shallow groundwater levels and rockhead depths $(<3 \mathrm{~m})$, subject to flooding with water depths of up to $3 \mathrm{~m}$, with steep slopes $(30 \%)$, the need for protection zones for natural springs, and potential construction problems, such as the occurrence of boulders and compressible layers (Figure 9). Regarding the subsurface drainage conditions, the basin had zones with very distinct characteristics. The areas constituted by the residual materials of the sandstones of the Botucatu Formation had characteristics very favorable to the infiltration and storage capacity of the geological materials, while the areas with transported sandy materials had good infiltration capacity but overlaid residual materials from the Serra Geral and Itaqueri Formations with lower hydraulic conductivity values. Areas constituted by the residual materials of the Serra Geral and Itaqueri Formations had more restrictive subsurface drainage conditions than the aforementioned areas due to the lower hydraulic conductivity values. Regarding potential hazardous events, the areas subject to flooding are delimited in the constraints map (Figure 9), while the potential for collapse is associated with the porosity and genetic characteristics of the unconsolidated sandy and sandy-clayey transported materials and residual materials of the Botucatu and Serra Geral Formations and the presence of compressible layers in the alluvial areas. The residual unconsolidated materials of the Serra Geral and Itaqueri Formations, especially the saprolitic layers, may contain clay minerals with swelling potential.

Regarding the subsurface drainage conditions (Figure $9 b$ ), the basin was divided into five zones based on the attributes listed in Figures 2 and 3 and the respective classes shown in Table 1.

Zone 1-This zone presented the most favorable subsurface drainage conditions, consisting of an upper layer of residual unconsolidated materials from the sandstones of the Botucatu Formation and an outcropping or layer of sandy transported materials. Both had $\mathrm{K}$ values greater than $10^{-4} \mathrm{~cm} / \mathrm{s}$, porosity on the order of $50 \%$, and thicknesses greater than $10 \mathrm{~m}$. Flow was predominantly in the condition of a porous medium.

Zone 2-This zone had less favorable conditions than zone 1, composed of a layer of transported unconsolidated materials with thicknesses greater than $10 \mathrm{~m}$, porosity between $40 \%$ and $50 \%$, and $\mathrm{K}$ greater than $10^{-4} \mathrm{~cm} / \mathrm{s}$ covering the residual unconsolidated materials from the Serra Geral or Itaqueri Formation, both of which had lower K values and porosity, generating a water interface, which hinders the drainage of infiltrated water and can generate directed flows and even a perched saturated zone.

Zone 3-This zone differed from zone 2 only by the thickness of the surface layer, which varied between 5 and $10 \mathrm{~m}$, thus generating a smaller storage capacity.

Zone 4-This zone consisted of the residual unconsolidated materials from the Serra Geral and Itaqueri Formations that may occur in some parts covered by a thin layer of sandy transported materials $(<3 \mathrm{~m})$, with the total thickness of the unconsolidated material package ranging from 3 to $5 \mathrm{~m}$. The residual materials had $\mathrm{K}$ values lower than those of the transported materials on the order of $10 \times$ or more, generating water interfaces. These conditions hinder the flow of infiltrated water and affect the efficiency of the systems and may generate perched saturated zones and directed flows.

Zone 5-This zone consisted of alluvial and sandy-clayey transported materials with a saturated zone depth of less than $3 \mathrm{~m}$. 


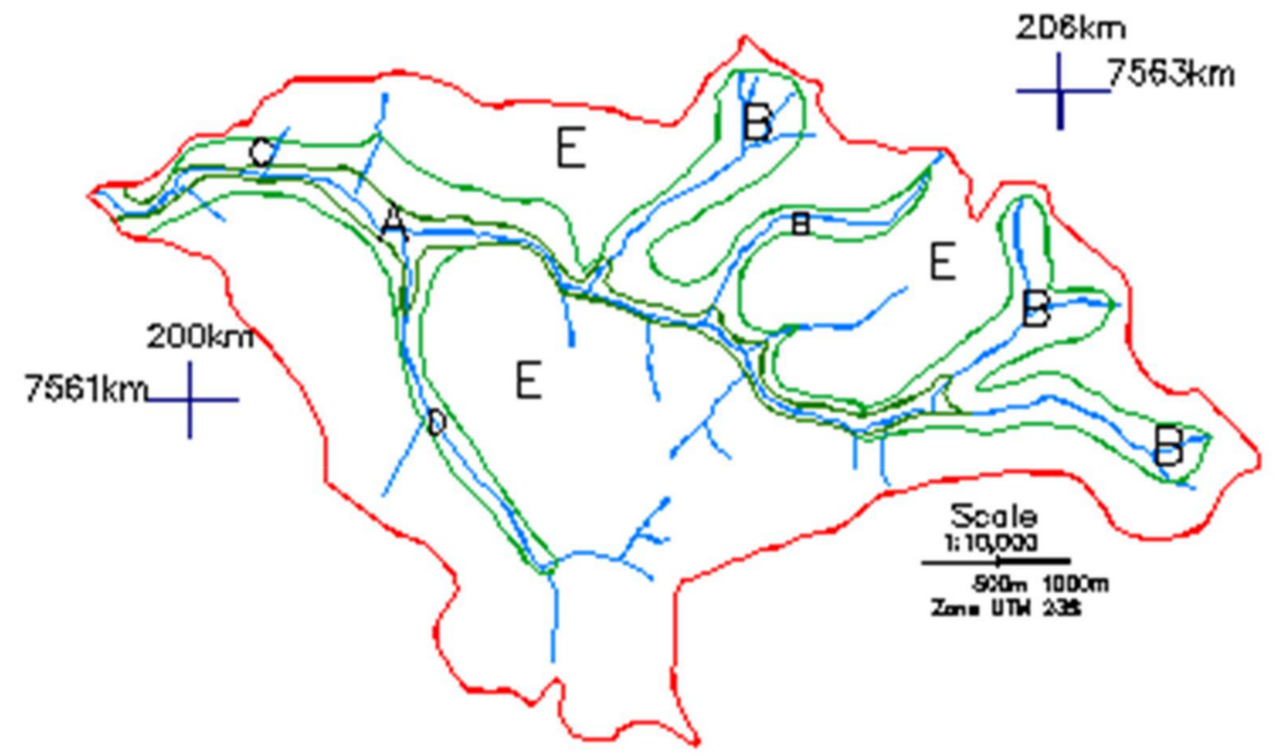

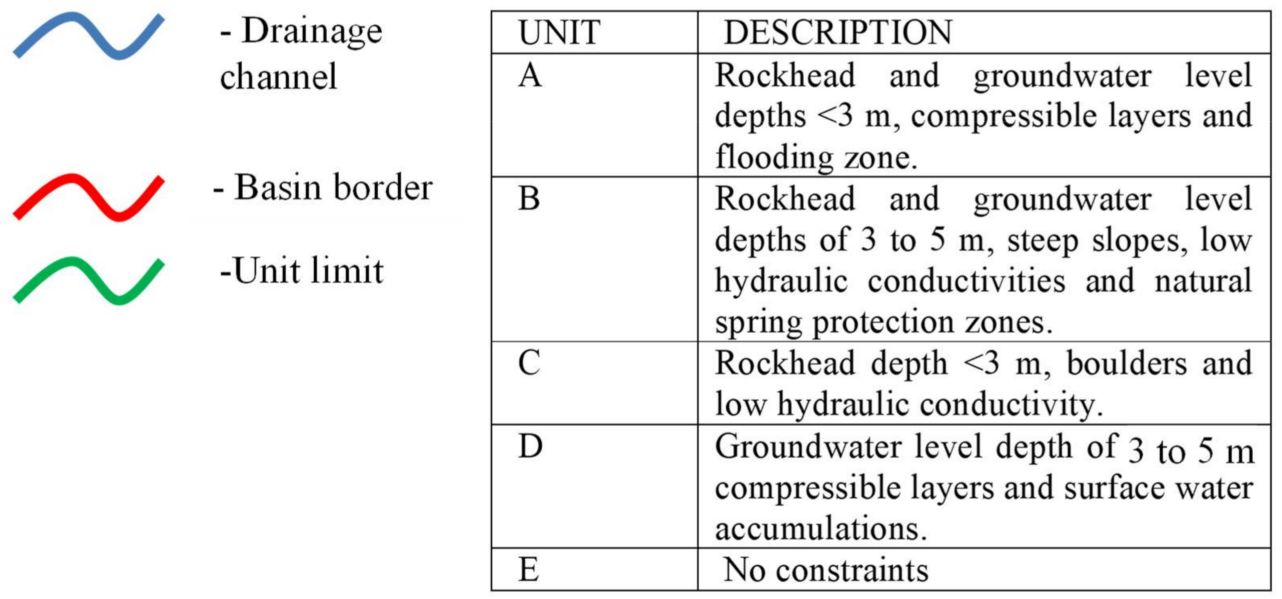

(a)

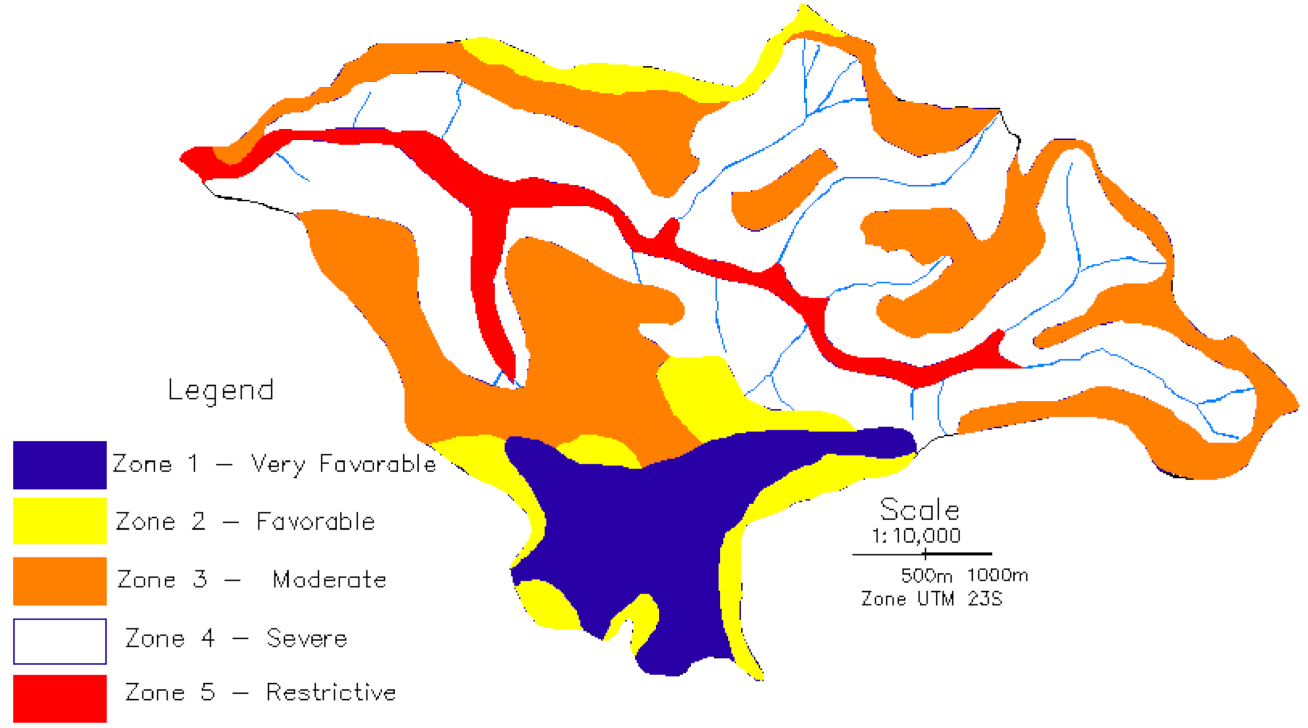

(b)

Figure 9. Cont. 


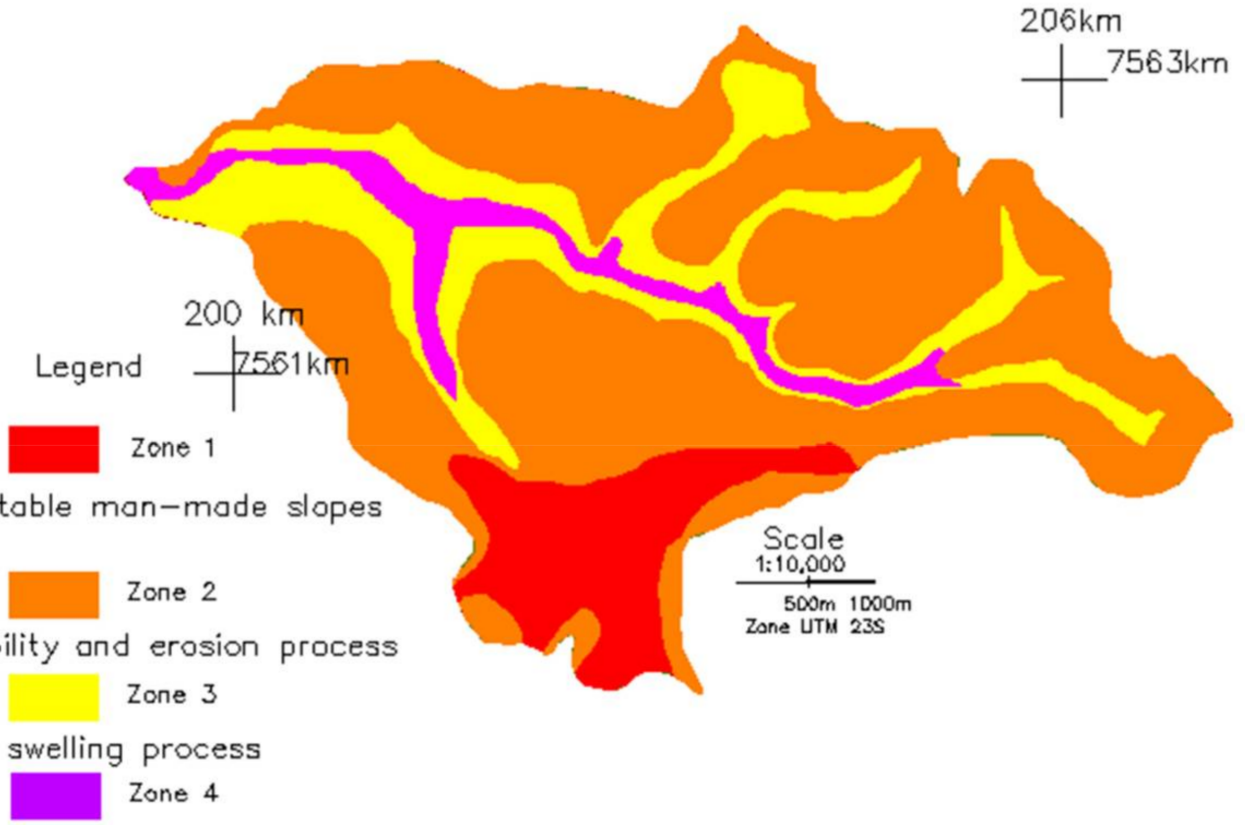

Potential collapsibility, unstable man-made slopes and erosion process

Zone 2
Potential collapsibility and erosion pr
Zone 3
Potential swelling process
Zone 4
Potential compressibility process

(c)

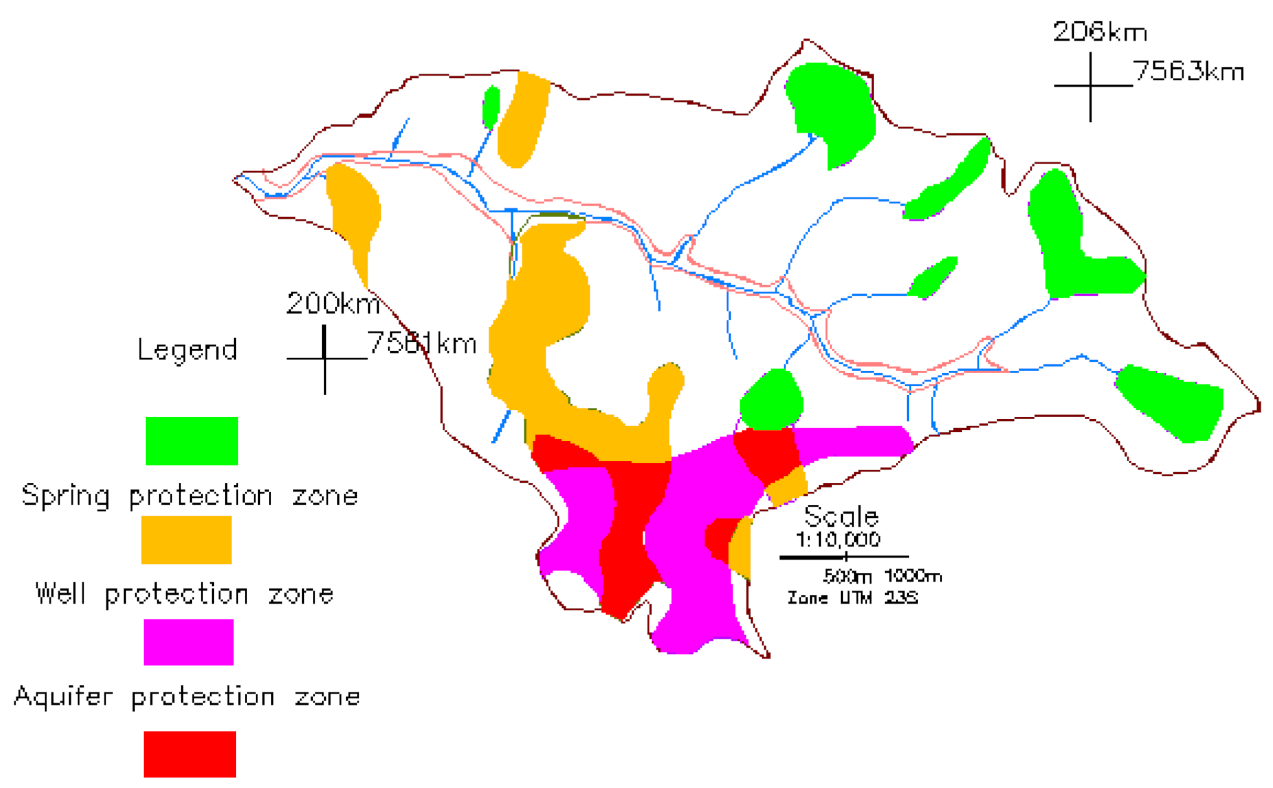

Aquifer and well protection zone

(d)

Figure 9. Specific maps of the main aspects considered to assess suitability. Functional and constructive constraints (a), subsurface drainage conditions (b), stability conditions (c), and protection zones (d).

\subsection{Zoning}

Considering the basic results (Figure 8, Tables 2 and 3) in Supplementary Material Table S1 and Table S2 and the intermediate analyses (Figure 9), zoning of the basin regarding suitability for the implementation of SuDSs was performed. The area was subdivided into five units that include different characteristics considered very favorable, favorable, moderate, severe, or restrictive. The units were subdivided into subunits based on specific functional, constructive, subsurface drainage, groundwater contamination, and stability 
characteristics. Figure 10 shows the zoning map, and Supplementary Material Table S3 provides the fundamental characteristics of each unit and subunit as well as some basic guidelines regarding constructive, functional, and environmental problems. Based on the characteristics of each unit/subunit, the potential of each type of system was analyzed. Based on the groundwater level and rockhead depth and the permeability, porosity, and storage capacity characteristics of geological material, units 1 and 2 had the potential for a considerable range of SuDS types, while unit 3 had a more restricted potential. Notably, the most favorable infiltration conditions were presented by unit 2, but this unit also had the greatest potential for groundwater contamination, and it is advisable to adopt systems that allow the use of horizontal permeable reactive barriers in accordance with the guidelines presented in $[47,48]$. Units 1 and 3 had water interfaces that can affect the efficiency of infiltration-based systems; these interfaces were higher in unit 3 than in unit 1.

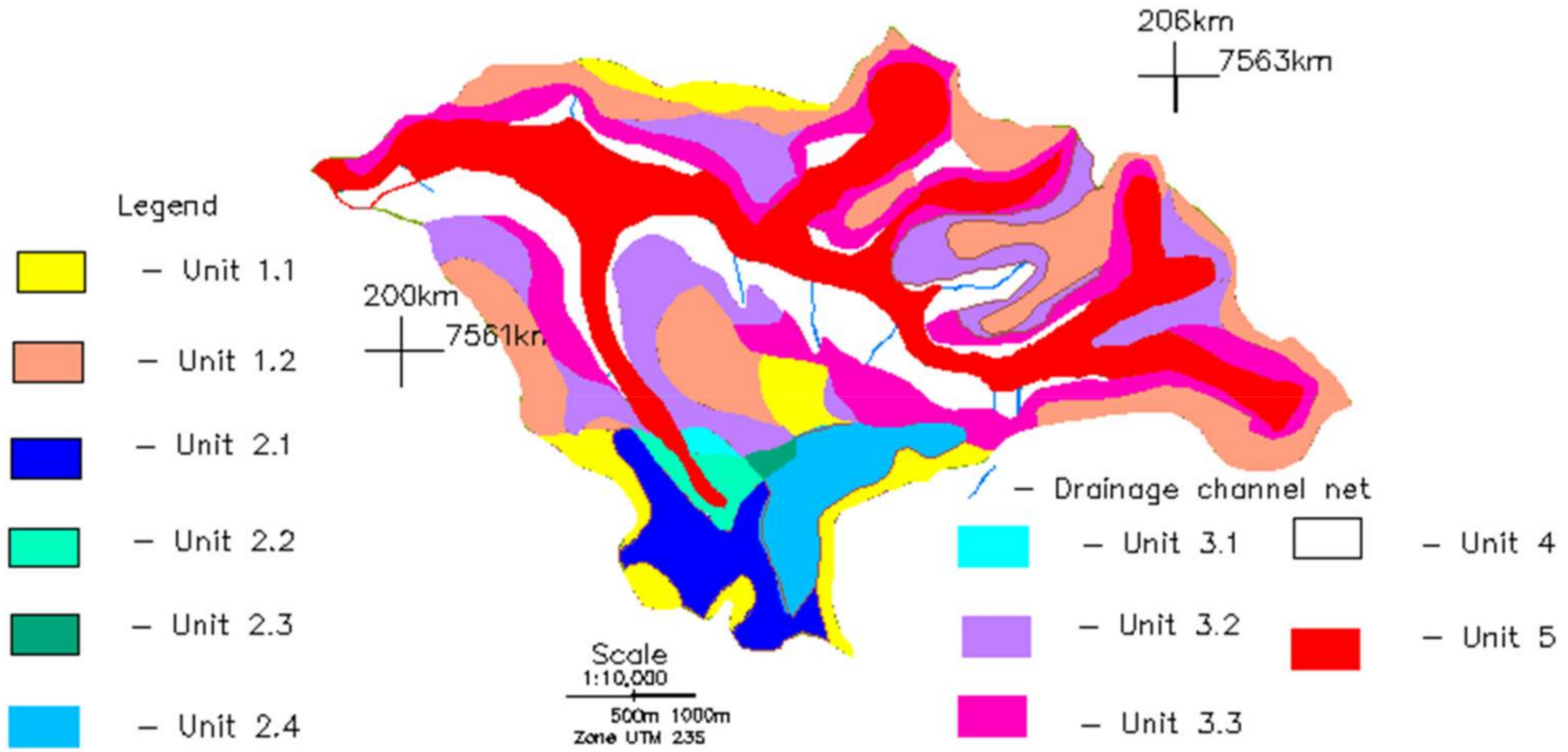

Figure 10. Sustainable drainage system (SuDS) suitability zoning map.

\section{UNIT 1}

This unit had favorable conditions for the installation of the following types of SuDSs, as long as certain aspects of construction were considered: soakaway, attenuation storage tank, infiltration basin, infiltration trench, infiltration blanket, bioretention system, pond, pervious surface, pervious pavement, geocellular system, filter drain, and perforated pipe.

1 -The surface layer of the geological materials constituting this unit had conditions favorable to collapse that could reach more than $5 \mathrm{~m}$; therefore, the systems should be installed at safe distances from building foundations.

2-The first $2 \mathrm{~m}$ was often compacted and, thus, contained restrictive saturated hydraulic conductivity levels; this layer should be excavated, and the base of the system should be installed at depths greater than $2 \mathrm{~m}$. Alternatively, this layer should be excavated and replaced with a layer of material having a favorable $\mathrm{K}$ value. Thus, after choosing specific site, penetrometer surveys should be performed for the diagnosis of compaction and depth.

3-In the case of a well or spring protection zone, the potential for surface runoff water to be contaminated with chemical products classified as hazardous should be considered, and the systems should be set up at a minimum distance of $50 \mathrm{~m}$ and downstream of the well when considering the flow of water from the saturated zone. 


\section{UNIT 2}

The areas included in this unit had favorable functional and subsurface drainage conditions for the following SuDS types: soakaway, attenuation storage tank, infiltration basin, infiltration trench, infiltration blanket, bioretention system, pond, pervious surface, pervious pavement, geocellular system, filter drain, and perforated pipe. Considering the two aspects cited, unit 2 had the most favorable conditions in the basin but had other aspects that may be constraining, such as the presence of recharge areas of the main aquifer and geological materials that have a low protection capacity due to the low sorption and retardation capacity. Conversely, geological materials have high erodibility and low cohesion, which favors the instability of excavated slopes. It is recommended that the systems be implemented with protection measures, such as permeable reactive barriers, as proposed by $[47,48]$. Thus, the installation of systems with a lower runoff accumulation magnitude should be prioritized, as they allow better control of possible contaminants and the area affected by infiltration, in addition to reducing installation costs. When water exploration wells are present, protection zones should be considered, and depending on the characteristics of the geological materials present in this zone and a lowering on the order of $30 \mathrm{~m}$, the influence radius should be between 300 and $350 \mathrm{~m}$.

\section{UNIT 3}

This unit consisted of the same geological materials as in unit 1, but the groundwater level and rockhead depths were shallower, imposing constraints on the suitability of SuDSs. The greatest differences from unit 1 were the subsurface drainage conditions and the storage capacity of infiltrated water. These conditions lead to a decrease in the depth of the systems $(<3 \mathrm{~m})$ and, consequently, in the volume of water that would be collected for infiltration because the layer with favorable conditions was seated on a layer with lower K values. These conditions lead to the accumulation of water and the occurrence of a parallel flow to the surface, which may generate unstable conditions in portions of the terrain with steeper slopes. Given these conditions, the systems with the greatest potential for use in this unit are tree plantations, attenuation storage tanks, pervious pavement, sand filters, filter drains or perforated pipes, and soakaways.

\section{UNIT 4}

The areas included in this unit consisted of geological materials with hydraulic conductivities smaller than those of units 1,2, and 3 and with less favorable subsurface drainage and storage conditions due to the geological materials. At shallow depths, layers with minerals with potential for swelling may be found, potentially affecting the stability of excavations. Due to the constraints found, the systems that meet some conditions for use are filter strips, swales, extended detention basins, sand filters, tree plantations, and attenuation storage tanks.

\section{UNIT 5}

The areas included in this unit had constraints in all aspects that affect the efficiency of infiltration-based drainage systems and, therefore, do not assist in regulating surface water runoff.

\section{Discussion}

The maps and data generated from the group of attributes (Table 1) and their respective classes allow the analysis of the suitability of each plot of land for different types of SuDSs. For each unit, it is possible to evaluate the relationships of each SuDS with rainfall events and scenarios of extreme rainfall events and analyze future rainfall variations due to global climate change. The selection of the most compatible SuDS type for each terrain unit can greatly decrease runoff volume and bring benefits of different magnitudes in terms of flood control, erosion, and protection of infrastructure lines, as highlighted by [49,50].

The basic sequence for application of the proposed procedures is represented in a simplified way in the flowchart presented in Figure 11, and the spatial extent analysis 
and data treatment can be performed with the use of GIS software or other computational systems depending on the methods, technological resources, and terrain unit adopted at the beginning of each study. In other words, the proposed procedure is flexible, which permits it to be applied easily in other areas.

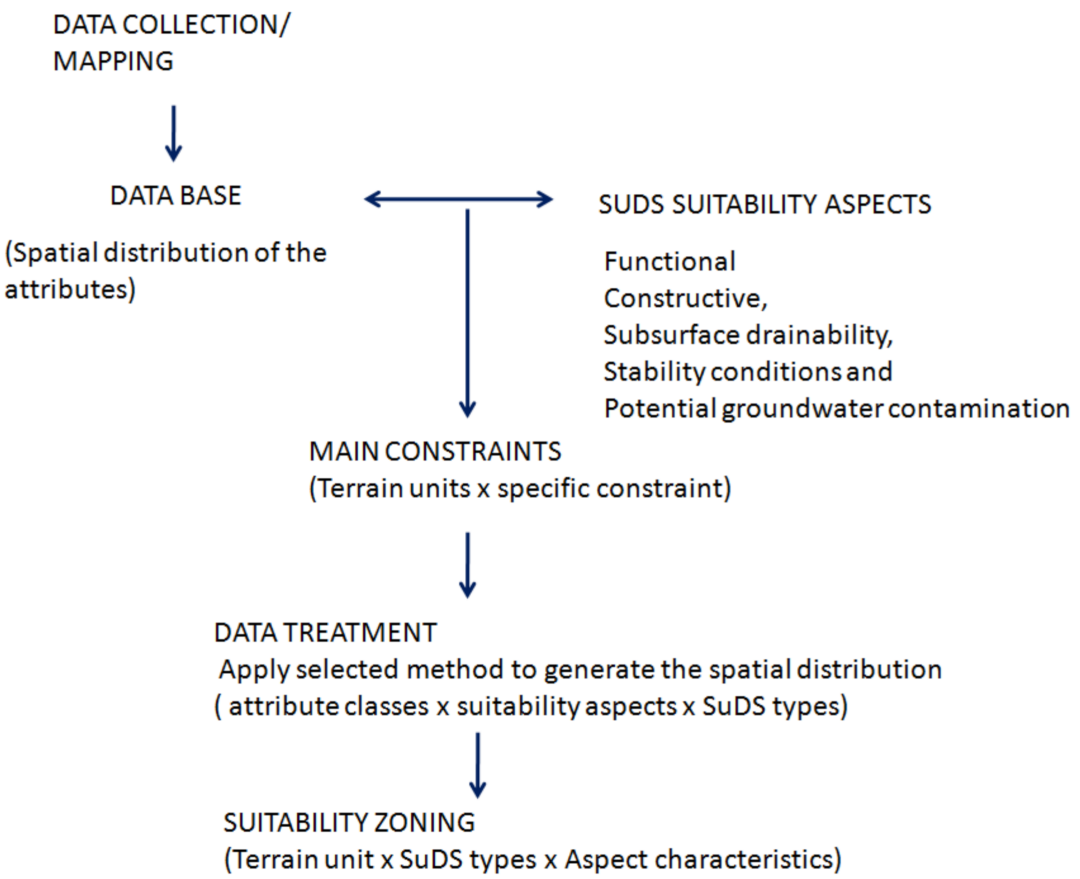

Figure 11. Basic sequence of the main steps to apply the procedures.

The geological material data in terms of depth allow the evaluation of the maximum infiltration and storage potential for each location, thus guiding the implementation of each specific SuDS. These data also allow planners to select among the possible SuDSs that will present the best efficiency/cost relationship, as observed by [51,52]. Figure 12 shows the conditions of each unit in relation to different aspects that influence the suitability for the implementation of SuDS. From these data, the planner and designer can assess the potential of each unit and estimate possible environmental and construction-related problems. For example, in the present study area, the stability conditions aspect affects most of the suitability units at a moderate to restrictive level, indicating the need for specific care in the design and implementation. However, in comparison, functional condition aspects constrained the implementation of SuDSs to a lower degree.

Based on the characteristics of each zone, the potential of each type of system was analyzed. Regarding the groundwater level and rockhead depth combined with the permeability, porosity, and storage capacity characteristics of geological material, units 1 and 2 had potential for a wide range of SuDS types, while unit 3 had a more restricted potential. Notably, the most favorable infiltration conditions were presented by unit 2, but this unit also had the greatest potential for groundwater contamination, and it is advisable to adopt systems that allow the use of horizontal permeable reactive barriers in accordance with the guidelines presented in $[47,48]$. Units 1 and 3 had water interfaces that could affect the efficiency of infiltration-based systems; these interfaces were higher in unit 3 than in unit 1.

The suitability of each type of SuDS in relation to the zoning units can be observed in Figure 13. It is noted that in some units, several types of SuDS were suitable, and in other cases, the majority were restricted. This information will allow the designer and planner to verify the feasibility of implementing different types of SuDSs in urbanized and nonurbanized areas. In Figure 14, the percentage of each type of SuDS is presented in relation to the total area of the basin. It is observed that most of the SuDSs could be 
applied in more than $50 \%$ of the study area, but others present potential suitability for a smaller percentage of the basin, as observed in other studies [21]. However, it is necessary to analyze the objective of the SuDS to verify the feasibility of the other techniques if they can be implemented in the zoning unit.

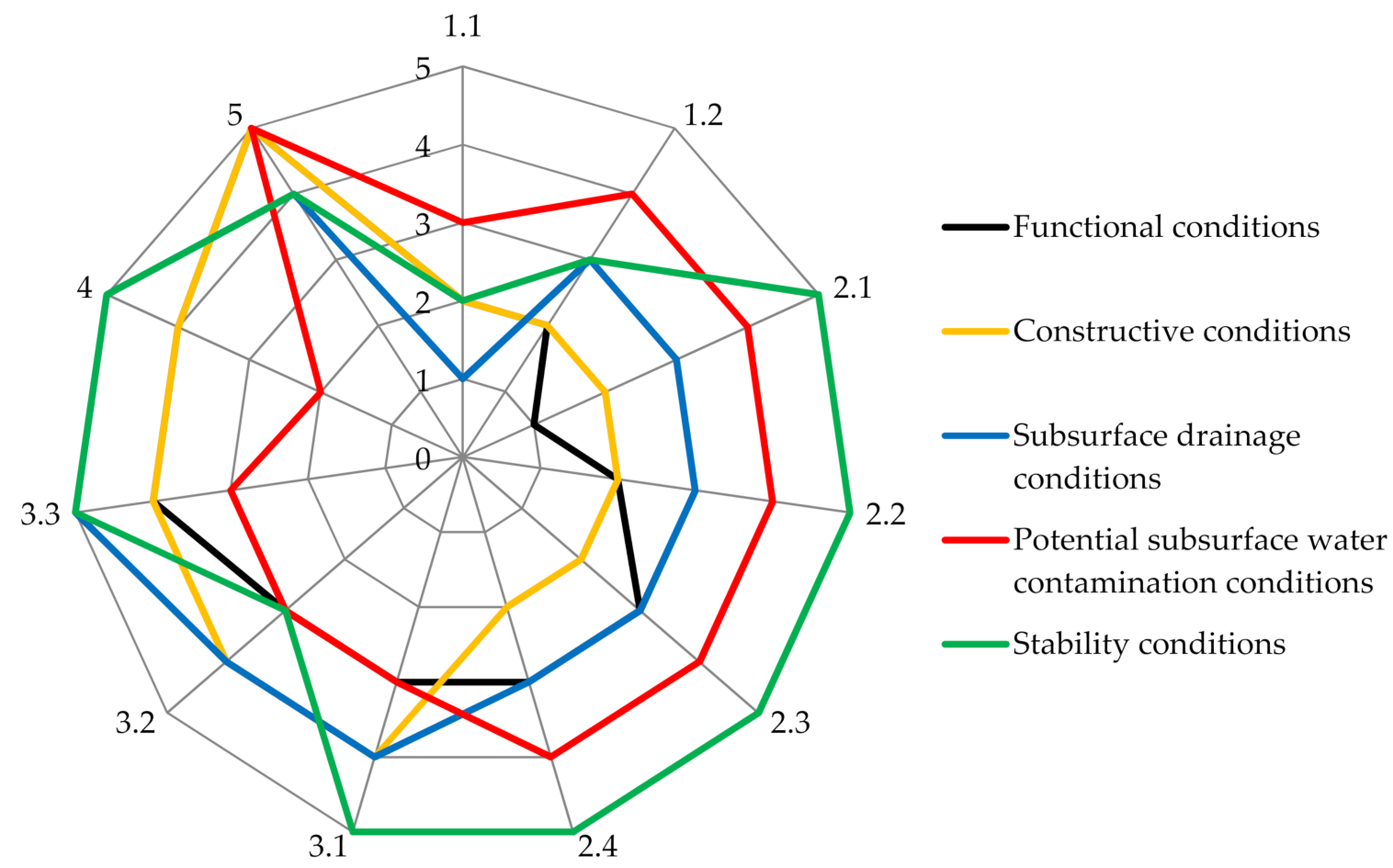

\section{Zoning units}

Figure 12. Relationship between suitability zones and the aspects that affect the suitability of sustainable drainage systems. Legend: 1—favorable, 2—favorable/moderate, 3-moderate, 4-severe, 5 -restrictive.

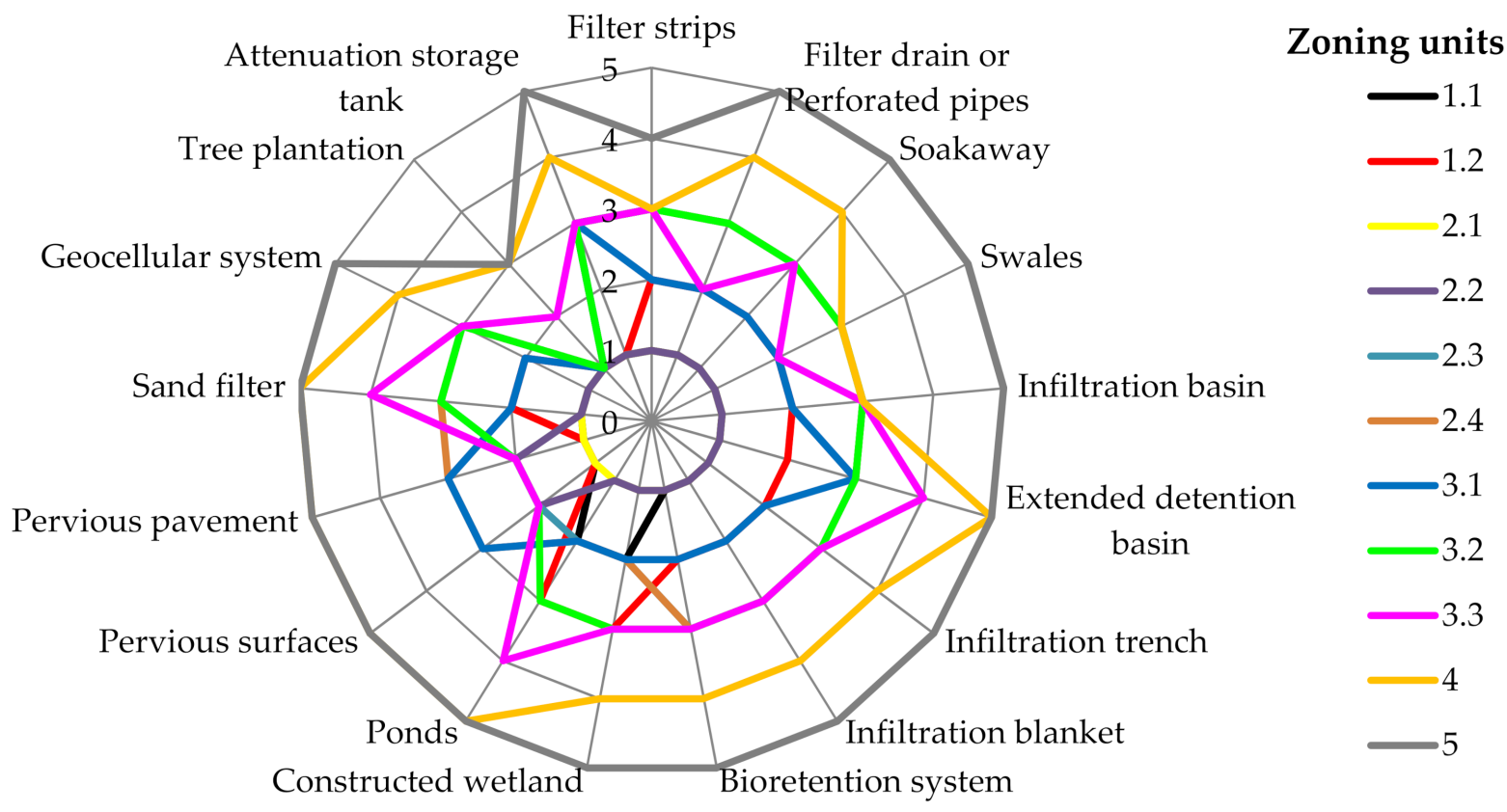

Figure 13. SuDS suitability for the zoning units. Legend: 1-favorable, 2-favorable/moderate, 3-moderate, 4-severe, 5-restrictive. 


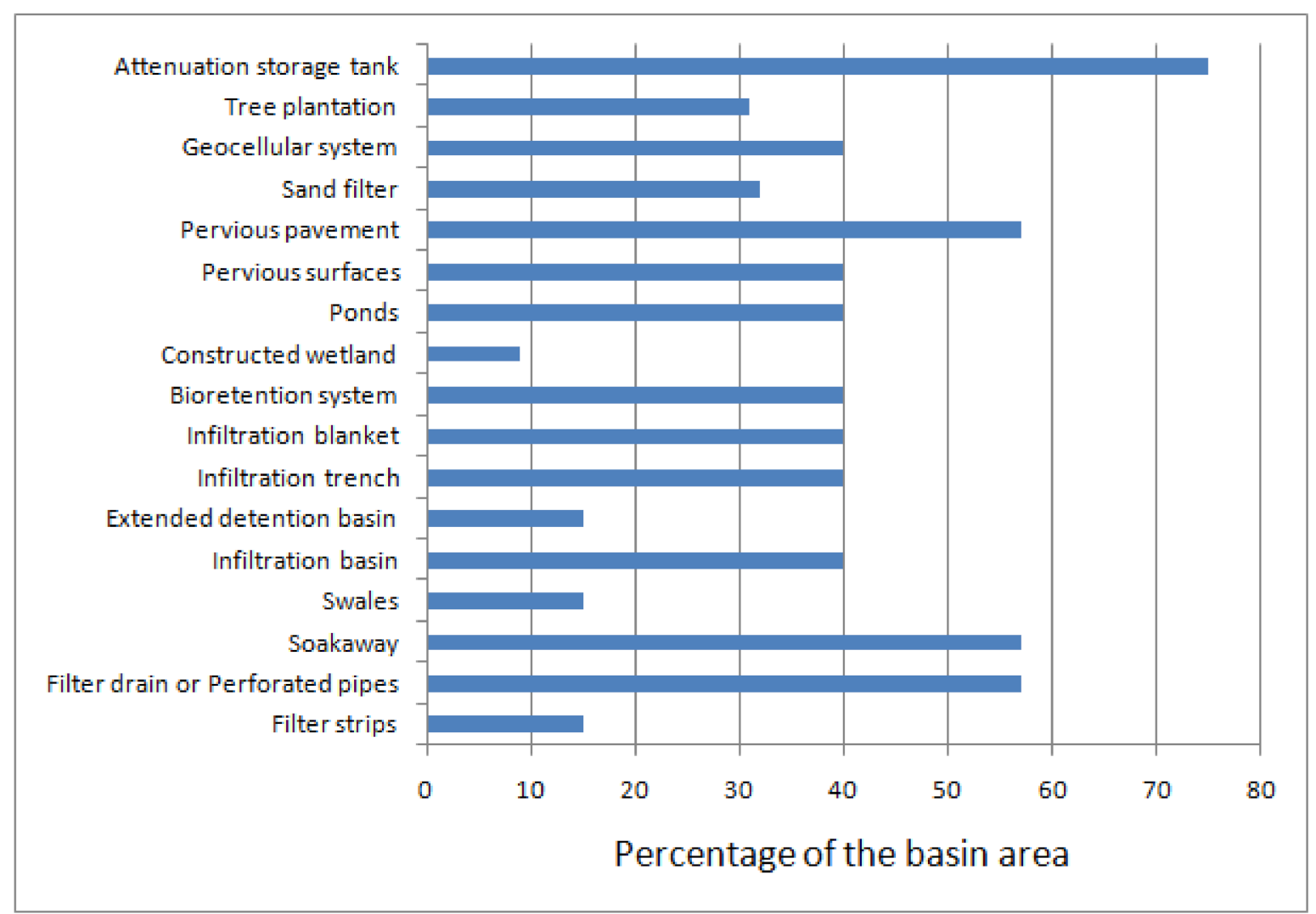

Figure 14. Relations between SuDSs and percentage of the study area.

\section{Conclusions}

This study proposes a set of procedures based on a group of attributes related to different environmental components, providing information that allows the assessment of the suitability of various SuDS types as well as the development of the respective projects and construction plans. The suitability zoning results in the detailed division of an area, with data ranging from favorable to constraining for the functionality and construction, subsurface drainage, stability, and potential groundwater contamination conditions. The zoning allows the adoption of different types of SuDSs to be analyzed considering different rainfall events, as well as the information needed to address global climate change and anthropogenic changes such as increased urbanization and the effects of compaction due to the excavation and use of surface layer materials. Moreover, this approach enables the development of analyses to verify the feasibility of taking recovery measures in portions of the area to partially restore the natural infiltration capacity, allowing much of the volume of rainfall to infiltrate and not generate substantial volumes of runoff.

The procedure is simple and inexpensive and can be applied at scales larger than $1: 25,000$ since data are available in detailed and compatible scales, allowing the suitability of SuDSs for different units in varying terrain types to be evaluated. It is essential to consider the detail of the scale because small variations in the data can make certain systems and construction conditions unfeasible. Despite the extensive list of proposed attributes, the magnitude of their influence affects the suitability of an area for a SuDS and can create environmental problems. The results can be presented in ways other than hierarchical categories, as used in this study. These procedures could contribute to the decision-making process for the selection of SuDSs to reduce flooding and environmental and economic losses in urban and rural basins. The results can be applied in the definition of the rules used as support for territorial planning and management and guidelines for different land uses. 
Supplementary Materials: The following supporting information can be downloaded at: https: / / www.mdpi.com/article/10.3390/su14052577/s1, Table S1: Unconsolidated materials and basic descriptions.; Table S2: Geological and geotechnical characteristics of unconsolidated material units; Table S3: Synthesis of suitability zoning for SuDSs.

Author Contributions: Conceptualization, M.F., N.P., O.P. and L.Z.; data curation, M.F., N.P., O.P. and L.Z.; formal analysis, M.F., N.P., O.P. and L.Z.; funding acquisition, N.P.; investigation, M.F., N.P., O.P. and L.Z.; methodology, M.F., N.P., O.P. and L.Z.; project administration, L.Z.; writing-original draft, M.F., N.P., O.P. and L.Z.; writing-review and editing, M.F., N.P., O.P. and L.Z. All authors have read and agreed to the published version of the manuscript.

Funding: This research received external funding from CNPq (The Brazilian National Council for Scientific and Technological Development) and Coordenação de Aperfeiçoamento de Pessoal de Nível Superior-Brasil (CAPES).

Data Availability Statement: The basic data was obtained from $\mathrm{PhD}$ and master dissertations obtained in https: / /www.teses.usp.br/ (accessed on 25 October 2021).

Conflicts of Interest: The authors declare no conflict of interest.

\section{References}

1. Sharma, S. Geological Behaviours in Urban Areas for Surface Runoff and Recharge. Open J. Soil Sci. 2017, 7, 181-201. [CrossRef]

2. Andersen, T. Detailed Geophysical Mapping and Hydrogeological Characterisation of the Subsurface for Optimal Placement of Infiltration-Based Sustainable Urban Drainage Systems. Geosciences 2020, 10, 446. [CrossRef]

3. Zuquette, L.; Failache, M.; Barbassa, A. Assessment of Depressional Wetland Degradation, Spatial Distribution, and Geological Aspects in Southern Brazil. Geosciences 2020, 10, 296. [CrossRef]

4. Coulthard, T.; Frostlick, L. The Hull floods of 2007: Implications for the governance and management of urban drainage systems. J. Flood Risk Manag. 2010, 3, 223-231. [CrossRef]

5. Jacobson, C.R. Identification and quantification of the hydrological impacts of imperviousness in urban catchments: A review. J. Environ. Manag. 2011, 92, 1438-1448. [CrossRef] [PubMed]

6. Kazmierczak, A.; Cavan, G. Surface Water Flooding Risk to Urban Communities: Analysis of Vulnerability, Hazard and Exposure. Landsc. Urban Plan. 2011, 103, 185-197. [CrossRef]

7. Rotta, C.M.D.S.; Zuquette, L.V. Assessment of environmental degradation due to anthropogenic processes based on critical zones: A study in a basin in southern Brazil. Environ. Earth Sci. 2021, 80, 1-21. [CrossRef]

8. Butler, D.; Parkinson, J. Towards sustainable urban drainage. Water Sci. Technol. 1997, 35, 53-63. [CrossRef]

9. Martin, P. Sustainable Urban Drainage Systems-Design Manual for England and Wales; CIRIA: London, UK, $2000 ;$ pp. 1-124.

10. Martin., P.; Turner, B.; Waddington, K. Sustainable Urban Drainage Systems-Design Manual for Scotland and Northern Ireland; CIRIA: London, UK, 2000; pp. 1-124.

11. CIRIA. SUDS Techniques. Available online: http://www.ciria.org/suds/suds_techniques.htm (accessed on 10 December 2020).

12. Charlesworth, S.M.; Harker, E.; Rickard, S.A. Review of sustainable drainage systems (SuDS): A soft option for hard drainage questions? Geography 2003, 88, 99-107.

13. Ellis, J.B.; Deutsch, J.C.; Mouchel, J.M.; Scholes, L.; Revittm, D. Multicriteria decision approaches to support sustainable drainage options for the treatment of highway and urban runoff. Sci. Total Environ. 2004, 334, 251-260. [CrossRef]

14. Dearden, R.; Price, S. A national suitability dataset for infiltration-based sustainable drainage systems. In Eleventh International Conference on Computing and Control for the Water Industry; Savic, D., Kapelan, Z., Butler, D., Eds.; Centre for Water Systems, University of Exeter: Exeter, UK, 2011; pp. 253-258.

15. Dearden, R.A.; Price, S.J. A proposed decision-making framework for a national infiltration SuDS map. Manag. Environ. Qual. Int. J. 2012, 23, 478-485. [CrossRef]

16. Dearden, R.A.; Marchant, A.; Royse, K. Development of a suitability map for infiltration sustainable drainage systems (SuDS). Environ. Earth Sci. 2013, 70, 2587-2602. [CrossRef]

17. Zhou, Q. A Review of Sustainable Urban Drainage Systems Considering the Climate Change and Urbanization Impacts. Water 2014, 6, 976-992. [CrossRef]

18. Bockhorn, B.; Klint, K.E.S.; Locatelli, L.; Park, Y.-J.; Binning, P.J.; Sudicky, E.; Jensen, M.B. Factors affecting the hydraulic performance of infiltration based SUDS in clay. Urban Water J. 2015, 14, 125-133. [CrossRef]

19. Woods, B.W.; Wilson, S.; Udale-Clarke, H.; Illman, S.; Scott, T.; Ashley, R.; Kellagher, R. The SUDS Manual; CIRIA: London, UK, 2015.

20. Dearden, R.A. User Guide for the Infiltration SuDS Map: Detailed; NERC: Nottingham, UK, 2011; p. 41. Available online: http:/ / nora.nerc.ac.uk/id/eprint/16618/ (accessed on 25 October 2021).

21. Charlesworth, S.; Warwick, F.; Lashford, C. Decision-Making and Sustainable Drainage: Design and Scale. Sustainability 2016, 8, 782. [CrossRef]

22. Horton, B.; Digman, C.J.; Ashley, R.M.; Gill, E. BeST (Benefits of SuDS Tool) Technical Guidance; CIRIA: London, UK, 2015. 
23. Dearden, R.A. User Guide for the Infiltration SuDS Map: Overview. British Geological Survey Open Report; CIRIA: London, UK, 2012; p. 31.

24. Bregulla, J.; Powell, J.; Yu, C. A Simple Guide to Sustainable Drainage Systems for Housing. NHBC Foundation. 2010. Available online: http:/ / www.observatorio2030.com/sites/default/files/2019-11/GU_116_2010_GB_52_A\%20simple\%20guide\%20to\% 20Sustainable\%20Drainage\%20Systems\%20for\%20housing.pdf (accessed on 15 February 2020).

25. Essex County Council (ECC) (2014) Sustainable Drainage Systems Design Guide. Available online: https:/ / cbccrmdata.blob.core. windows.net/noteattachment/suds\%20design\%20guide.pdf.pdf (accessed on 15 February 2020).

26. CIRIA. West of England Sustainable Drainage Developer Guide Section; CIRIA: London, UK, 2015. Available online: https: / / www.bristol.gov.uk/documents / 20182/34524/West+of+England+sustainable+drainage+developer+guide+section+1/86 4fe0d2-45bf-4240-95e2-a9d1962a0df9 (accessed on 25 February 2020).

27. CIRIA. SuDS in London-A Guide; CIRIA: London, UK, 2016. Available online: http://content.tfl.gov.uk/sustainable-urbandrainage-november-2016.pdf (accessed on 20 February 2020).

28. Staffordshire County Council. Sustainable Drainage Systems (SuDS) Handbook; Arcadis Consulting: Stanfordshire, UK, 2017. Available online: https://www.staffordshire.gov.uk/environment/Flood-Risk-Management/Documents/SuDS-Handbook.pdf (accessed on 13 March 2020).

29. Hockenhull, J. Sustainable Drainage Systems (SuDS) Handbook; Arcadis Consulting: Herefordshire, UK, 2018. Available online: https: //www.herefordshire.gov.uk/downloads/file/14026/sustainable-drainage-systems-handbook (accessed on 15 February 2020).

30. Gibson, C. Sustainable Drainage Systems (SuDS) Handbook; Arcadis Consulting: London, UK, 2019.

31. Andrés-Doménech, I.; Anta, J.; Perales-Momparler, S.; Rodriguez-Hernandez, J. Sustainable Urban Drainage Systems in Spain: A Diagnosis. Sustainability 2021, 13, 2791. [CrossRef]

32. Archer, N.A.L.; Bell, R.A.; Butcher, A.S.; Bricker, S.H. Infiltration efficiency and subsurface water processes of a sustainable drainage system and consequences to flood management. J. Flood Risk Manag. 2020, 13, e12629. [CrossRef]

33. Ferrans, P.; Torres, M.; Temprano, J.; Sanches, J. Sustainable Urban Drainage System (SUDS) modeling supporting decision-making: A systematic quantitative review. Sci. Total Environ. 2022, 806, 150447. [CrossRef]

34. Gimenez-Maranges, M.; Breuste, J.; Hof, A. Sustainable Drainage Systems for transitioning to sustainable urban flood management in the European Union: A review. J. Clean. Prod. 2020, 255, 120191. [CrossRef]

35. McClymont, K.; Cunha, D.G.F.; Maidment, C.; Ashagre, B.; Vasconcelos, A.F.; de Macedo, M.B.; dos Santos, M.F.N.; Gomes, M.N., Jr.; Mendiondo, E.M.; Barbassa, A.P.; et al. Towards urban resilience through Sustainable Drainage Systems: A multi-objective optimisation problem. J. Environ. Manag. 2020, 275, 111173. [CrossRef]

36. Viavattene, C.; Ellis, J.B. The management of urban surface water flood risks: SUDS performance in flood reduction from extreme events. Water Sci. Technol. 2013, 67, 99-108. [CrossRef] [PubMed]

37. Failache, M. Proposta de Procedimentos Para a Estimativa de Infiltração Potencial e do Escoamento superficial Hortoniano Potencial Baseada em Dados Geológicos, Geotécnicos, de Uso e Ocupação e Eventos de Chuva. Ph.D. Thesis, University of São Paulo, São Paulo, Brazil, 2018.

38. Zuquette, L. Mapeamento Geotécnico Preliminar na Região de Sao Carlos. Master's Thesis, Universidade de São Paulo, São Paulo, Brazil, 1981.

39. Nishiyama, L. Mapeamento Geotécnico Preliminar da Quadricula de São Carlos-SP. Master's Thesis, Universidade de São Paulo, São Paulo, Brazil, 1991.

40. Aguiar, R.L. Mapeamento Geotécnico da Area de Expansão Urbana de São Carlos—SP. Master's Thesis, Universidade de São Paulo, São Paulo, Brazil, 1989.

41. Pons, N.A.D. Levantamento e Diagnóstico Geológico-Geotécnico de Areas Degradadas na Cidade de São Carlos-SP, Com Auxílio de Geoprocessamento. Ph.D. Thesis, Universidade de São Paulo, São Paulo, Brazil, 2006.

42. Pons, N.A.D.; Pejon, O.J.; Zuquette, L.V. Use of geoprocessing in the study of land degradation in urban environments: The case of the city of São Carlos, state of São Paulo, Brazil. Environ. Geol. 2007, 53, 727-739. [CrossRef]

43. Zuquette, L.V. Análise Crítica da Cartografia Geotécnica e Proposta Metodológica Para Condições Brasileiras. Ph.D. Thesis, Universidade de São Paulo, São Paulo, Brazil, 1987.

44. Zuquette, L.V. A Importância do Mapeamento Geotécnico no Uso e Ocupação do Meio do Meio Físico: Fundamentos e Guia Para Elaboração. Free Teaching Thesis, Universidade de São Paulo, São Paulo, Brazil, 1993.

45. Matula, M. Regional engineering geological evaluation for planning purposes. Bull. Int. Assoc. Eng. Geol. 1979, 19, 18-24. [CrossRef]

46. Zuquette, L.V.; Pejon, O.J.; Collares, J.Q.D.S. Land degradation assessment based on environmental geoindicators in the Fortaleza metropolitan region, state of Ceará, Brazil. Environ. Earth Sci. 2003, 45, 408-425. [CrossRef]

47. Rocha, L.C.C.; Zuquette, L.V. Evaluation of Zeolite as a Potential Reactive Medium in a Permeable Reactive Barrier (PRB): Batch and Column Studies. Geosciences 2020, 10, 59. [CrossRef]

48. Rocha, L.C.C.; Zuquette, L.V. Estudo de meio reativo para barreiras reativas permeáveis (brp): Ensaios laboratoriais. Geosciences 2020, 39, 1025-1040. [CrossRef]

49. Morgan, M.; Fenner, R. Spatial evaluation of the multiple benefits of sustainable drainage systems. In Proceedings of the Institution of Civil Engineers-Water Management; Thomas Telford Ltd.: London, UK, 2019; Volume 172, pp. 39-52. [CrossRef] 
50. Fengxiang, Q. Influencing Factors and Strategies for Sustainable Urban Drainage System. Civ. Eng. Res. J. 2018, 3, 555616. [CrossRef]

51. Oladunjoye, O.A.; Proverbs, D.G.; Collins, B.; Xiao, H. A cost-benefit analysis model for the retrofit of sustainable urban drainage systems towards improved flood risk mitigation. Int. J. Build. Pathol. Adapt. 2019, 38, 423-439. [CrossRef]

52. Lashford, C.; Charlesworth, S.; Warwick, F.; Blackett, M. Modelling the Role of SuDS Management Trains in Minimising Flood Risk, Using MicroDrainage. Water 2020, 12, 2559. [CrossRef] 